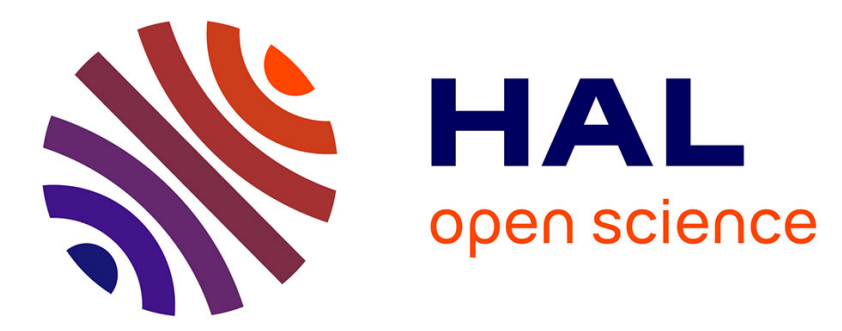

\title{
Mobilisation of rare earth elements in shear zones: Insights from the Tabouchent granodioritic pluton (Jebilet massif, Variscan Belt, Morocco)
} Abderrahim Essaifi, Alicja M Lacinska, Michel Corsini, Kathryn M Goodenough, Amal El Arabaoui, Rachid Zayane

\section{To cite this version:}

Abderrahim Essaifi, Alicja M Lacinska, Michel Corsini, Kathryn M Goodenough, Amal El Arabaoui, et al.. Mobilisation of rare earth elements in shear zones: Insights from the Tabouchent granodioritic pluton (Jebilet massif, Variscan Belt, Morocco). Ore Geology Reviews, In press, 10.1016/j.oregeorev.2021.103996 . hal-03112847

\section{HAL Id: hal-03112847 \\ https://hal.science/hal-03112847}

Submitted on 17 Jan 2021

HAL is a multi-disciplinary open access archive for the deposit and dissemination of scientific research documents, whether they are published or not. The documents may come from teaching and research institutions in France or abroad, or from public or private research centers.
L'archive ouverte pluridisciplinaire HAL, est destinée au dépôt et à la diffusion de documents scientifiques de niveau recherche, publiés ou non, émanant des établissements d'enseignement et de recherche français ou étrangers, des laboratoires publics ou privés. 


\section{Journal Pre-proofs}

Mobilisation of rare earth elements in shear zones: Insights from the Tabouchent granodioritic pluton (Jebilet massif, Variscan Belt, Morocco)

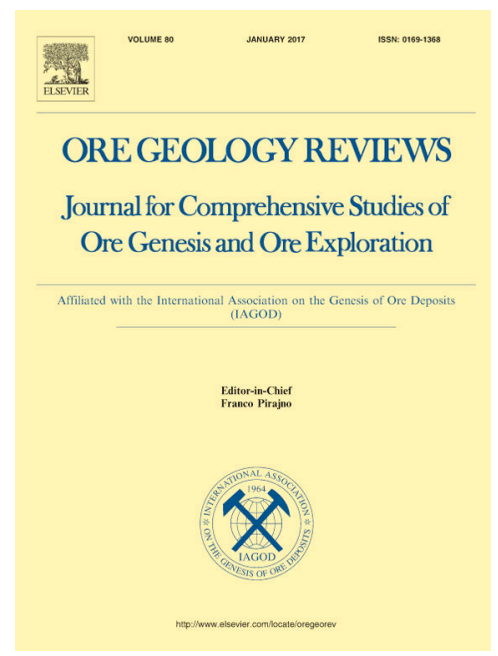

Abderrahim Essaifi, Alicja M. Lacinska, Michel Corsini, Kathryn M.

Goodenough, Amal El Arabaoui, Rachid Zayane

S0169-1368(21)00021-4

PII: https://doi.org/10.1016/j.oregeorev.2021.103996

DOI:

OREGEO 103996

To appear in:

Ore Geology Reviews

Received Date:

14 October 2020

Revised Date:

23 December 2020

Accepted Date:

8 January 2021

Please cite this article as: A. Essaifi, A.M. Lacinska, M. Corsini, K.M. Goodenough, A. El Arabaoui, R. Zayane, Mobilisation of rare earth elements in shear zones: Insights from the Tabouchent granodioritic pluton (Jebilet massif, Variscan Belt, Morocco), Ore Geology Reviews (2021), doi: https://doi.org/10.1016/j.oregeorev. 2021.103996

This is a PDF file of an article that has undergone enhancements after acceptance, such as the addition of a cover page and metadata, and formatting for readability, but it is not yet the definitive version of record. This version will undergo additional copyediting, typesetting and review before it is published in its final form, but we are providing this version to give early visibility of the article. Please note that, during the production process, errors may be discovered which could affect the content, and all legal disclaimers that apply to the journal pertain.

Crown Copyright (C) 2021 Published by Elsevier B.V. All rights reserved. 
Article

\title{
Mobilisation of rare earth elements in shear zones: Insights from the Tabouchent granodioritic pluton (Jebilet massif, Variscan Belt, Morocco)
}

\author{
Abderrahim Essaifi ${ }^{1, *}$, Alicja M. Lacinska ${ }^{2}$, Michel Corsini ${ }^{3}$, Kathryn M. \\ Goodenough $^{4}$, Amal El Arabaoui', Rachid Zayane ${ }^{1}$
}

${ }^{1}$ Geology department, Cadi Ayyad University, BP. 2390, Marrakech, Morocco

${ }^{2}$ British Geological Survey, Environmental Science Centre, Keyworth, Nottingham NG12 5GG, UK

${ }^{3}$ Geoazur, CNRS UMR6526, Université Nice Sophia Antipolis, Valbonne, France

${ }^{4}$ British Geological Survey, The Lyell Centre Research Avenue South, Edinburgh EH14 4AP, UK

* Corresponding author (email: essaifi@uca.ac.ma)

\begin{abstract}
In the Jebilet massif (Variscan belt, Morocco), two peraluminous granodioritic plutons (the Eastern and Central Jebilet plutons) are spatially associated with a regional shear zone. The Central Jebilet pluton includes the Tabouchent, Bramram and Bamega intrusions, which represent variably eroded portions of an arcuate apical part of the pluton. The intrusions are composed of biotite \pm cordieritebearing granodiorite that is crosscut by tourmaline-bearing leucogranite, which is greisenized in the Bramram cupola. Fluorine, $\mathrm{Sn}-\mathrm{W}(\mathrm{Au})$ mineralization is present in the pluton while $\mathrm{Cu}-\mathrm{Au}$ and $\mathrm{Pb}-\mathrm{Zn}$ Ag-Au mineralizations are present in the contact metamorphic aureole around the intrusion.

Deformation is more homogeneous in the Bramram and Bamega than in the Tabouchent granodioritic intrusion where deformation is very heterogeneous and concentrated within conjugate subvertical meter-scale ductile shear zones that crosscut the intrusion. In the shear zones the breakdown of feldspar and biotite resulted in the transformation of the granodiorite to phyllonites composed of quartz
\end{abstract}


+ muscovite \pm chlorite. ${ }^{40} \mathrm{Ar} /{ }^{39} \mathrm{Ar}$ dating on white mica allowed us to date the regional shearing event to $305.9 \pm 0.9$ Ma.

Fluid-rock interaction in the shear zones resulted in mobilization of rare earth elements (REE) and other major and trace elements. $\mathrm{Na}$ and $\mathrm{Ca}$ are typically leached from the shear zones while $\mathrm{K}$ and volatiles are gained. REE mobilisation was decoupled from that of the major elements and was accompanied by fractionation between light and heavy REE. It was mainly controlled by the alteration of magmatic accessory REE-bearing phases, predominantly monazite, followed by the reprecipitation of syntectonic monazite, xenotime, $\mathrm{Th}+\mathrm{Ca} \pm \mathrm{REE}$ phosphate, Ce oxide and REE fluorocarbonates. Other typical changes in the shear zones are enrichments in Sn, W, As and Sb.

The mineralogical and chemical changes recorded in the shear zones that crosscut the granodiorite are similar to those associated with the greisenization that affected the Bramram leucogranite. They indicate that the shear zones provide pathways for rising acidic magmatic fluids exsolved from S-type leucogranites.

Keywords: Rare earth elements, shear zones, fluid flow, metal zonation, Variscan, Morocco

\section{Introduction}

Shear zones are major crustal structures that are well known as pathways for fluid circulation and metasomatic processes. One of the most common reactions that result from fluid-rock interaction in crustal shear zones is the breakdown of K-feldspar and plagioclase to white mica (Wibberley and McCaig, 2000). This reaction assisted by advection of hydrous fluids is a mechanism often invoked for promoting localized deformation in granitoids at the brittle-ductile transition (e.g. Bos and Spiers, 2001; Gueydan et al., 2003; Jefferies et al., 2006; Wintsch et al., 1995). Formation of mica-rich mylonites, which can culminate in phyllonite development, is accompanied by changes in major and trace element chemistry (Goncalves et al., 2012; Hippertt, 1998; Rossi et al., 2005; Sinha et al., 1986; Streit and Cox, 1998). Typical major element mobilities associated with feldspar breakdown in granitoid shear zones are losses of $\mathrm{Na}, \mathrm{Si}, \mathrm{K}$ and $\mathrm{Ca}$ in volume loss shear zones, and $\mathrm{Si}$ gain in constant volume and volume gain shear zones (SZ) while Al and Ti remain generally immobile in both SZ types (Bailey et al., 1994; Condie and Sinha, 1996; Tursi et al., 2018). However, the behaviour of the REE and other trace elements is less systematic; they could be either mobile or immobile depending on the composition of the hydrothermal fluids (Ague, 2017; Essaifi et al., 2004; Selverstone et al., 1991; Williams-Jones et al., 2012). It has been documented that the changes in REE concentrations related to fluid-rock interaction in shear zones are commonly decoupled from the changes in the major mineral assemblages and associated changes in major element concentrations (Ague, 2017; Rolland et al., 2003). The behaviour of REE during fluid-rock interactions depends rather on the stability of the minerals in which they are hosted, the P-T conditions and the composition of the percolating fluid (Bea, 1996; Ward et al., 1992; Williams-Jones et al., 2012). Numerous studies have dealt with the interaction of REE-minerals with 
fluids, both naturally (e.g. Chen and Zhou, 2017; Poitrasson et al., 2000; Vasyukova and Williams-Jones, 2016) and experimentally (e.g. Budzyn et al., 2011; Geisler et al., 2003; Harlov et al., 2005). These studies, together with the theoretical predictions of the behaviour of REE in aqueous solutions (Haas et al., 1995; Migdisov and Williams-Jones, 2014; Wood, 1990), provide a basis for interpretation of the REE transfer by upper crustal geological fluids.

In this paper, we investigate the effects of fluid circulation on the mobility of elements during mylonitization of the peraluminous Variscan Tabouchent granodioritic pluton (Jebilet massif, Morocco). Fluid flow was highly channelized in a vertical, meter-scale shear zone network where the granodioritic protolith is transformed into a phyllonite composed of quartz + muscovite \pm chlorite. The associated metasomatic changes involve the transfer of major elements and a variety of REE behaviours including little or no REE mobility, LREE and/or HREE mobility, and local REE redistribution. Field relationships and microstructural evolution indicate that shear zone development was associated with emplacement of leucogranitic intrusions. Here, we test the hypothesis that hydrothermal alteration within the shear zones can be related to interaction between the crystallized granodiorite and upwelling acidic magmatic fluids exsolved from leucogranitic magmas. Such fluids caused greisenization at the regional scale and allowed formation of a variety of metal occurrences and deposits in the area.

\section{Geological setting}

The Jebilet massif is located north of Marrakech. It represents an E-W cross-section of the Variscan belt of Morocco, a southern extension of the Variscan belt of Europe (Fig. 1). The massif is composed of three structural units (Essaifi et al., 2001b; Huvelin, 1977). The Western Jebilet Unit includes a Cambro-Ordovician sedimentary sequence that was uplifted at the end of the Devonian and only weakly deformed during the Variscan (Huvelin, 1977; Piqué and Michard, 1989). The Central Jebilet Unit comprises a sedimentary sequence of Visean age named the Sarhlef Schists, (Huvelin, 1977; Playford et al., 2008) which was extensively deformed and metamorphosed at low grade during the Variscan orogeny (Delchini et al., 2016; Essaifi et al., 2001b). The Eastern Jebilet Unit comprises an Upper Visean sedimentary flysch sequence (the Kharrouba flysch) (Graham, 1982; Huvelin, 1977; Izart et al., 1997) that is overlain by tectonically emplaced nappes (Beauchamp et al., 1991; Graham, 1982). Two major tectonic structures separate the three units (i) a NNE-trending dextral thrust-wrench fault at the boundary between Central and Western Jebilet, which is part of the West Moroccan Shear Zone (Piqué et al., 1980), (ii) a NNW-trending sinistral wrench shear zone called the Marrakech Shear Zone (Essaifi et al., 2001b; Lagarde and Choukroune, 1982), marks the boundary between Central and Eastern Jebilet (Fig. 1).

The Sarhlef Schists underwent low-grade metamorphism and deformation during the Variscan orogeny (Bordonaro et al., 1979; Delchini et al., 2018; Essaifi et al., 2001a; Huvelin, 1977). Huvelin (1977) identified the presence of two major phases of deformation and folding. Schistosity and stretching lineation development occurred during the same late Carboniferous deformation, which is the main Variscan tectonic event in Morocco (Lagarde et al., 1990; Michard et al., 2010; Piqué and Michard, 1989). The main regional cleavage $\left(S_{1}\right)$ typically trends NNE-SSW (Fig. 2 ) and is axial planar to a series of open upright F1 folds (Essaifi et al., 2001b; Lagarde and Choukroune, 1982; Le Corre and Saquaque, 
1987). This cleavage bends into a series of shear zones, which have been divided into two groups forming map-scale anastomosing structures (Essaifi et al., 2001b). A group of typically $\mathrm{N}-\mathrm{S}$ trending sinistral shear zones is well developed across much of the Central Jebilet. It is interconnected by a group of ENE trending dextral shear zones that is associated with late major faults, such as the Mesret Fault (N'Diaye et al., 2016). The shear zones are associated with an increasing of strain, tightening of folds, and development of stretching lineation, then formation of curvilinear folds by rotation and deformation of pre-existing planar and linear structures during progressive deformation (Lagarde and Choukroune, 1982). A late brittle deformation episode is also recognized in the Jebilet Massif.

Variscan magmatism in the Jebilet massif includes a bimodal association of alkaline microgranites and mafic-ultramafic intrusions located in Central Jebilet (Aarab and Beauchamp, 1987; Bordonaro et al., 1979; Essaifi, 1995) and two peraluminous granodioritic plutons that are spatially associated with the Marrakech Shear Zone (Bensalah, 1989; Chemesseddoha, 1986; El Amrani, 1996) (Fig. 1). To the east of this shear zone, the Oulad Ouaslam granodiorite outcrops over an area of $190 \mathrm{~km}^{2}$ and forms an E-W sheet-like pluton, $30 \mathrm{~km}$ long and 3 to $10 \mathrm{~km}$ wide. To the west of the shear zone, the Central Jebilet pluton includes three intrusions, Bamega to the southwest, Tabouchent to the northwest, and Bramram to the east (Fig. 2). The Tabouchent and Bamega intrusions outcrop over an area of $22 \mathrm{~km}^{2}$ and form two intrusions with approximately the same dimensions $(4 * 3 \mathrm{~km})$ while the Bramram granitic intrusion has the smallest dimensions $(1 \mathrm{~km} * 0.5 \mathrm{~km})($ Fig. $2 \mathrm{~A})$. The three intrusions represent outcrops at the top of a single plutonic body whose upper interface with the country rocks is folded parallel to the main regional folding direction (Saquaque, 1985; Le Corre and Saquaque, 1987). The plutons consist mainly of biotite \pm cordierite-bearing granodiorite enclosing magmatic microgranular enclaves and partly digested pelitic xenoliths containing andalusite and sillimanite megacrysts (Bouloton, 1992; El Amrani, 1996). Tourmaline-bearing leucogranites (two-mica granites) are present in the plutons as decimetre to meter-scale dykes and stocks crosscutting the granodiorite and the country rocks (Fig. 4B, C). They display aplitic to pegmatitic textures. The leucogranites are well developed along the western margin of the Oulad Ouaslam pluton and along the boundaries between the country rocks and the Bamega and Tabouchent intrusions. The leucogranite forms the main part of the Bramram intrusion where it cuts across the granodiorite and shows an extensive hydrothermal transformation, leading to total disappearance of feldspar and formation of greisen composed of quartz, muscovite and tourmaline in the Bramram cupola (Bensalah, 1989; Huvelin, 1977). Pegmatite veins and dykes are also present in the plutons but they are well developed in the country rocks to the north of the granodioritic plutons, in the Sidi Bou Othmane area, where they form a dyke swarm trending NNE-SSW (Huvelin, 1977) (Fig. 1). These pegmatite veins, which are lithium-bearing and rich in accessory phosphate minerals (Fontan et al., I976; Huvelin, 1977), show syntectonic emplacement criteria: some veins are boudinaged and folded while others crosscut the penetrative schistose fabric.

In the Tabouchent intrusion two main types of granodiorite are exposed (i) to the east a coarsegrained porphyritic granodiorite where K-feldspar megacrysts $(2-5 \mathrm{~cm})$ are enclosed within a matrix (3$7 \mathrm{~mm}$ ) composed of quartz, plagioclase, K-feldspar, biotite and cordierite, (ii) to the west a coarsegrained granular $(4-6 \mathrm{~mm})$ granodiorite that is petrographically similar to the porphyritic granodiorite 
but almost megacryst-free. Other textural variations in the intrusion include a progressive evolution toward the contact with the host rocks where the matrix becomes microgranular $(2-5 \mathrm{~mm})$ and the Kfeldspar megacrysts become oriented parallel to the intrusion boundaries (El Amrani, 1994). These boundaries are generally occupied by the leucogranite, which forms an envelope that wraps the major part of the intrusion (Fig. 2). The leucogranite is also present as sheets, dykes and stocks intruding both the granodiorite and its wall rocks. The leucogranite is fine to medium grained and is composed of quartz, K-feldspar, plagioclase, muscovite, tourmaline, and occasionally relics of biotite, which was replaced by muscovite. Quartz-fluorine, quartz-tourmaline $\pm \mathrm{Sn}$ and $\mathrm{Sn}-\mathrm{Sb}(\mathrm{Au})$ veins occur in the intrusion where they are associated with the shear zones (Huvelin et al., 1980).

An age of ca. $327 \pm 4$ Ma was obtained for the granodioritic plutons and $295 \pm 15$ Ma for the crosscutting leucogranites by $\mathrm{Rb} / \mathrm{Sr}$ dating (Mrini et al., 1992). More recent $\mathrm{U}-\mathrm{Pb}$ dating has suggested somewhat older ages of $358 \pm 7$ to $336 \pm 4 \mathrm{Ma}$ for the granodiorites although the dates are characterised by some uncertainty due to inheritance and lead loss (Delchini et al., 2018). These ages overlap with those of the country rocks, whose fossil contents indicate a Visean (347-331 Ma) age (Huvelin, 1977; Playford et al., 2008). The granodiorites have relatively low zircon saturation temperatures $\left(<800^{\circ} \mathrm{C}\right)$ (Essaifi et al., 2014), similar to temperatures based on zircon typology and biotite geothermometry (El Amrani, 1996), and so zircon has the potential to contain inherited cores (Mohammadi et al., 2020). In any case, geochronological dating indicates a sustained and long-lasting magmatic activity in the Jebilet massif, between 350-330 Ma and ca. 300 Ma (Delchini et al., 2018; Dostal et al., 2005; Essaifi et al., 2003; Marcoux et al., 2008; Mrini et al., 1992). This magmatism is characterized by a temporal evolution from magmas of hybrid origin $\left(0.704<\left({ }^{87} \mathrm{Sr} /{ }^{86} \mathrm{Sr}\right)_{\mathrm{i} .}<0.7108 ;-6.7<\varepsilon \mathrm{Ed}_{\mathrm{i}}<4.1\right)$, to magmas of pure crustal origin $\left.\left({ }^{87} \mathrm{Sr} /{ }^{86} \mathrm{Sr}\right)_{\mathrm{i}}=0.7177 ; \varepsilon \mathrm{Nd}=-7.2\right)$, reflecting a lithosphere that is heated from below (Essaifi et al., 2014). Geodynamically, development of this magmatism occurred during the Late Carboniferous collision between Gondwana and Laurussia, following the closure of either the Rheic ocean (Michard et al., 2010; Simancas et al., 2009), or the Paleotethys ocean (Essaifi et al., 2014; Roddaz et al., 2002).

The plutons have induced in the surrounding metapelites a low-pressure contact metamorphism that reaches the pyroxene hornfels facies while only chlorite is stable far from the intrusions (Chemesseddoha, 1986; Le Corre and Saquaque, 1987). The developed contact metamorphic association includes cordierite and andalusite \pm sillimanite, and indicates a maximal pressure of $2.2 \mathrm{~kb}$ corresponding to a maximum depth of $8 \mathrm{~km}$ (Bouloton, 1992). These contact metamorphic minerals were retrogressed into quartz, muscovite and biotite \pm tourmaline. They disappear progressively towards the leucogranite sheets that occur chiefly at the margins of the central Jebilet pluton, leading Le Corre and Saquaque (1987) to suggest that retrogression of andalusite and cordierite was induced by emplacement of the fluid-rich leucogranite. The andalusite and cordierite-bearing schists extend to the north and cover the area of the pegmatite dyke swarm of Sidi Bou Othmane (Fig. 1), suggesting the presence of a granitic intrusion at depth (Delchini et al., 2016; El Hassani, 1982; Huvelin, 1977). The andalusite and cordierite bearing schists enclose many irregularly shaped limestone lenses, which were metamorphosed and transformed into skarns. In the metamorphosed aureole around the granodiorite, $\mathrm{Cu}-\mathrm{Au}$ and $\mathrm{Ag}-\mathrm{Pb}-\mathrm{Zn}$ Au vein mineralization is developed in the metapelitic rocks (El Arbaoui et al., 2019; Essarraj et al., 
2017; Huvelin, 1977) while graphite zones occur in scheelite and molybdenite-bearing metamorphic carbonates (Huvelin, 1977). The Cu-Au-bearing veins occur in the sandstones of Jebel Haimer, aproximately $1.5 \mathrm{~km}$ from the contact between the Tabouchent granodiorite and the country rocks, while the Ag-Pb-Zn-Au veins form the Roc Blanc deposit, which is located along the NNW-trending Marrakech Shear Zone, approximately $3 \mathrm{~km}$ to the northeast of the contact between Tabouchent granodiorite and the country rocks (Fig. 2A).

Structural mapping revealed that the bedding surfaces in the country rocks around the Central Jebilet pluton present a doming structure indicating that the erosion level reached only the apical parts of the pluton (Le Corre and Saquaque, 1987; Saquaque, 1985). Within the Oulad Ouaslam pluton strain is generally low, and the pre-full-crystallization planar fabric is weak or absent (Boummane and Olivier, 2007), but strain intensity increases towards the western margin of the pluton, which is strongly sheared along the regional Marrakech Shear Zone (Lagarde et al., 1990). Deformation is more homogeneous in the Bramram and Bamega intrusions, where foliation is subvertical and strikes N20 to N30, than in the Tabouchent intrusion where deformation is very heterogeneous (Lagarde, 1989; Le Corre and Saquaque, 1987; Saquaque, 1985), and concentrated within conjugate meter-scale ductile shear zones that crosscut the intrusion (Fig. 3). This style of deformation is similar to that described in the Kettara intrusion where metre to centimetre-scale shear zones bound lenticular metre to $100 \mathrm{~m}$-scale domains of weakly deformed to undeformed gabbros (Essaifi et al., 2004). The metre-scale shear zones are part of map-scale anastomosing shear zones that characterise Central Jebilet (Essaifi et al., 2001). Like the metre-scale shear zones of Kettara (N'diaye et al., 2016), the metre-scale shear zones of Tabouchent are part of a map-scale dextral shear zone, the Tabouchent Shear Zone, which rotates into the SSE Marrakech Shear Zone (Figs. 2, 3). Lagarde (1989) described the orthogneissification within the Tabouchent shear zones as a result of a low temperature deformation developed within a solidified and thermally re-equilibrated granodioritic pluton while orthogneissification of the leucogranites was related to a high temperature deformation developed during emplacement of the leucogranite.

\section{Field relationships, sampling strategy and analytical techniques}

\subsection{Field relationships and sampling strategy}

Deformation in the Tabouchent pluton is heterogeneous at both the outcrop scale and the intrusion scale, varying from weakly deformed granodiorites to mylonites and ultramylonites. There is a general increase in the intensity of deformation towards the peripheral zones of the pluton where the leucogranites are foliated and display S/C structures (Le Corre and Saquaque, 1987). However, the most prominent deformation gradients are observed towards subvertical metre-scale shear zones where the granodiorites are transformed into mylonites and ultramylonites, in the outer parts and inner parts of the shear zones, respectively (Fig. 4A, D-J). The shear zone network of Tabouchent has two main components, one trending NNW-SSE with a sinistral strike-slip sense and the other ENE-WSW with a dextral sense (Fig. 3). The shear zones crosscut both the foliated and the undeformed granites, and locally transect the pluton margins, continuing into the country rocks. A subhorizontal stretching lineation is generally associated with these shear zones, which locally display late slip striae. The $070^{\circ}$ dextral component and the $\mathrm{N} 160^{\circ}$ sinistral component of shear zones are consistent with an overall horizontal 
NW-SE shortening and NE-SW extension at the scale of the intrusion. This shortening direction corresponds to that inferred from foliation trajectories, major fold trends, and syn-folding conjugate wrench faults at the scale of the Jebilet massif (Essaifi et al., 2001b) and the Moroccan Meseta (Lagarde et al., 1990).

The leucogranites are also affected by shearing. The western side of the Oulad Ouaslam pluton is composed of highly sheared leucogranites. In the Tabouchent pluton, there is a strain gradient towards the margins of the intrusion where the leucogranite is deformed and displays $\mathrm{C} / \mathrm{S}$ structures. Within the intrusion, leucogranite dykes are parallel to shear zones, or in some cases offset by late brittle-ductile shear zones.

Mesoscopic veins are spatially associated with the shear zones. They include (i) up to $10 \mathrm{~cm}$ wide quartz-tourmaline-bearing fractures locally present in the center of the shear zones, (2) up to $20 \mathrm{~cm}$ wide mesoscopic quartz-calcite veins localized along the shear zone walls. Within the quartz-tourmaline veins, tourmaline is localized in the centre whilst quartz at the margins. These veins strike in WNW and ENE directions; they are affected by ductile deformation marked by recrystallization of quartz grains and their stretching parallel to the shear zones. Mineralization composed essentially of cassiterite and arsenopyrite is locally associated with these veins (Huvelin, 1980). The quartz-calcite veins are generally parallel to the shear zones, but they are not affected by ductile deformation. Within the veins, quartz is localized at the margins and calcite in the centre. These veins contain $\mathrm{Fe}$-oxides and $\mathrm{Cu}$-carbonates (malachite, azurite).

Several (11) margin-to-center horizontal sampling traverses were made through the Low Temperature metric shear zones that crosscut the granular granodiorite of the Tabouchent intrusion (Fig. $3)$. Each traverse includes two to three samples, collected 0.5-3m apart, including the weakly deformed to undeformed granodiorite through the highly deformed rocks in the inner parts of the shear zones. An additional shear zone sample and a leucogranite were collected in Tabouchent and one leucogranite and one greisen in Bramram intrusion.

\subsection{Analytical techniques}

The composition of silicate minerals was determined using a Cameca SX 100 electron microprobe at Montpellier University (Table 1). The identification of REE minerals and their qualitative analyses were performed at the Petrography and Microanalysis Laboratory, British Geological Survey (BGS), using an FEI Quanta 600 SEM with an Oxford Instruments X-Max $50 \mathrm{~mm}^{2}$ silicon drift detector (SDD) for EDS analysis running with Oxford Instruments INCA (v4) software. The SEM was operated at $20 \mathrm{kV}$ accelerating voltage and approximately $2 \mathrm{nA}$ beam current.

Whole rock analyses were undertaken as a means of investigating the effects of deformation and fluid-rock interaction on the mobilisation and distribution of REE (Table 2). Samples weighing up to $5 \mathrm{~kg}$ were crushed following a standard protocol to obtain adequate powder fractions using agate mortars. Chemical analyses were performed by the Service d'Analyse des Roches et des Minéraux (SARM; CRPG-CNRS, Nancy, France) using a ICP-AES for major-elements and a ICP-MS for trace elements following the techniques described in (Carignan et al., 2001). A total of 30 samples were 
analysed including 8 undeformed granodiorite and 21 mylonites to ultramylonites from the Tabouchent intrusion, in addition two leucogranites and one greisen from the Bramram intrusion (Fig. 3).

For ${ }^{40} \mathrm{Ar} /{ }^{39} \mathrm{Ar}$ dating, the samples were crushed and the $200-315 \mu \mathrm{m}$ size fraction was cleaned in ultrasonic bath. Ten grains of muscovite were carefully handpicked under a binocular microscope to select only grains without evidence of alteration or inclusions. Selected grains were packaged in aluminium foils and were irradiated for $97 \mathrm{~h}$ in the McMaster Nuclear Reactor together with Fish Canyon sanidine grains as flux monitor (28.030 $\pm 0.056 \mathrm{Ma}$, (Jourdan and Renne, 2007)). The argon isotopic interferences on $\mathrm{K}$ and $\mathrm{Ca}$ were determined by the irradiation of $\mathrm{KF}$ and $\mathrm{CaF}_{2}$ pure salts from which the following correction factors were obtained: $\left({ }^{40} \mathrm{Ar} /{ }^{39} \mathrm{Ar}\right)_{\mathrm{K}}=2.97 \times 10^{-2} \pm 10^{-3}$ at $1 \sigma,\left({ }^{38} \mathrm{Ar} /{ }^{39} \mathrm{Ar}\right)_{\mathrm{K}}=1,24$ x $10^{-2} \pm 5 \times 10^{-4}$ at $1 \sigma,\left({ }^{39} \mathrm{Ar} /{ }^{37} \mathrm{Ar}\right)_{\mathrm{Ca}}=7.27 \times 10^{-4} \pm 4 \times 10^{-5}$ at $1 \sigma$, and $\left({ }^{36} \mathrm{Ar} /{ }^{37} \mathrm{Ar}\right)_{\mathrm{Ca}}=2.82 \times 10^{-4} \pm 3 \times$ $10^{-5}$ at $1 \sigma \cdot{ }^{40} \mathrm{Ar} /{ }^{39} \mathrm{Ar}$ step heating analyses were performed at Géoazur Nice (France) using a continuous $100 \mathrm{~W}$ Photon Machine $\mathrm{CO}_{2}$ (IR) laser used at 5-15\% during $30 \mathrm{~s}$. Argon isotopes were measured in static mode using an ARGUS VI mass spectrometer from Thermo-Fischer. Measurements were carried out in multi-collection mode using four Faraday cups equipped with $10^{12} \mathrm{ohm}$ (masses 40, 39, 38 and 37) and one low-background compact discrete dynode ion counter to measure mass 36 . Collector gain calibration is performed by the computer-controlled application of predetermined voltages to each collector. Mass discrimination for the mass spectrometer was monitored by regularly analyzing air pipette volumes. The raw data were processed using the ArArCALC software (Koppers, 2002), and ages were calculated using the decay constants given by Steiger and Jäger (1977). Blanks were monitored after every three-sample analyses. All parameters and relative abundance values are provided in Table 3 (Annex) and have been corrected for blanks, mass discrimination, and radioactive decay. Atmospheric ${ }^{40} \mathrm{Ar}$ was estimated using a value of the initial ${ }^{40} \mathrm{Ar} /{ }^{36} \mathrm{Ar}$ of 298.56 (Lee et al., 2006). Our criteria for the determination of a plateau are as follows: a plateau must include at least $70 \%$ of ${ }^{39} \mathrm{Ar}$ released, over a minimum of three consecutive steps agreeing at $95 \%$ confidence level. Plateau ages are given at the $2 \sigma$ error level, and the plateau age uncertainties include analytical and J-value errors. All the errors on the inverse isochron, total fusion ages, and initial ${ }^{40} \mathrm{Ar} /{ }^{36} \mathrm{Ar}$ ratios are quoted at the $2 \sigma$ error.

\section{Mineral alteration and temperature conditions}

\subsection{Mineral alteration within the undeformed granodiorite}

Petrographical investigations show that the undeformed granodiorite underwent a pervasive hydrothermal alteration. Samples described in this paper are all from the coarse-grained granular facies of the granodiorite, which rarely contains phenocrysts. The least altered sample (TB8) is a coarse-grained granular biotite \pm cordierite-bearing granodiorite composed of quartz, plagioclase, K-feldspar, biotite \pm cordierite (Fig. 5A-B). Accessory minerals include ilmenite, zircon, monazite, xenotime, apatite and rare allanite. Feldspars represent 45 to 65 vol. \% of the granodiorite. The alkali feldspar (Or 81-94\%; Table 1) is sub-euhedral (4-6 mm) and hosts inclusions of biotite and plagioclase. It is perthite with flame-like sodic feldspar exsolution, and displays remnants of Carlsbad twinning. Plagioclase is subeuhedral to euhedral and shows polysynthetic twinning and a rough zoning (An 22-56\%), with development of sericite in its central parts. In samples where alteration is most pronounced, the whole crystal may be changed to a fine-crystalline aggregate of sericite. Quartz is interstitial, and some crystals 
show undulose extinction characteristic of intracrystalline deformation, or a limited recrystallization along the crystal borders. Biotite (up to 10 vol. \%) is brown, sub-euhedral to euhedral and locally deformed. It displays Fe-rich compositions $\left(2.45<\mathrm{XFe}=\mathrm{Fe}^{2+} / \mathrm{Fe}^{2+}+\mathrm{Mg}<2.76\right)$ and moderate to high $\mathrm{Ti}$ and $\mathrm{Al}$ contents $\left(\mathrm{TiO}_{2}=3.26-4.96 \mathrm{wt} \% ; \mathrm{Al}_{2} \mathrm{O}_{3}=15.23-16.73 \mathrm{wt} \%\right.$; Table 1). It falls within the primary field of biotite, and at the transition between the fields of peraluminous and calc-alkaline granites (El Amrani, 1994; El Arabaoui, 2018). Biotite is commonly partially altered to chlorite and muscovite, and contains numerous inclusions of zircon, monazite, apatite, and Fe-Ti oxides. Complete replacement of biotite by chlorite and muscovite occurs in the most altered samples. Where present, cordierite forms 3$4 \mathrm{~mm}$ globular spots commonly transformed into pinite and muscovite.

The REE-bearing minerals occur as inclusions within the major silicates, especially within biotite where they are surrounded by well-developed alteration coronas (Fig. 5A). Based on the abundance distribution Feature-INCA analysis, zircon makes up ca 70\% of all REE bearing phases, followed by monazite ca $20 \%$, xenotime ca $10 \%$ and REE phases associated with Th and F ca $2 \%$. Due to analytical difficulty, apatite was excluded from this count, but its abundance is similar to that of xenotime. Zircon occurs as euhedral to subhedral, $<50 \mu \mathrm{m}$ crystals commonly associated with xenotime (Fig. 6). Monazite, up to $100 \mu \mathrm{m}$ across, occurs as individual crystals, in places associated with zircon or apatite. Monazite often contains inclusions of Th-rich phases and is locally zoned with respect to Th and likely other elements (Fig. 6B). Xenotime crystals are less than $50 \mu \mathrm{m}$ in size and are often intergrown with zircon, likely postdating it (Fig. 6A). Primary apatite crystals up to $100 \mu \mathrm{m}$ are euhedral, prismatic and included in all the major mineral phases, indicating that apatite is an early-crystallized phase. Inclusions within apatite comprise $<1 \mu \mathrm{m}$ crystals of REE-bearing Th-silicate and $\mathrm{Th}+\mathrm{Ca}-$ phosphate (Fig. 6A). Allanite is relatively rare but crystals up to $150 \mu \mathrm{m}$ were observed. Allanite surrounded by epidote occurs as inclusions within biotite. Such allanite-cored epidote is most likely of primary origin. It was described in peraluminous granites of hybrid origin (Healy et al., 2004), as is the case of the Tabouchent granodiorite (Essaifi et al., 2014; Mrini et al., 1992).

\subsection{Mineral alteration in the shear zones}

Deformation within the shear zones is characterized by an increase in strain from the outer parts to the inner parts of the shear zones. In the mylonitic granodiorite, this progression is reflected by grainsize reduction, progressive disappearance of feldspar, and elongation of polycrystalline quartz ribbons with undulose extinction (Figs. 4G-J; 5C-F). Deformation of K-feldspar and plagioclase is accommodated by pervasive microfracturing and pressure solution leading to grain-size reduction and reorientation of the fine-grained matrix along the foliation plane. Plagioclase crystals in the outer parts of the shear zones are albitized and sericitized, while a concomitant alteration into muscovite leads to the disappearance of feldspars in the inner parts of the shear zones. Biotite, which is bent and partially transformed into chlorite and muscovite in the outer parts of the shear zones, is absent in the inner parts of the shear zones. With increasing strain, the large quartz grains of the original granitoid are plastically deformed and recrystallized into fine grains forming polycrystalline quartz ribbons in the highly deformed zones. In sum, the inner parts of the shear zones are ultramylonites composed mainly of quartz, muscovite, chlorite, $\mathrm{Fe}$ and $\mathrm{Ti}$ oxides and sulphide minerals (pyrite, arsenopyrite). The strong 
ultramylonitic foliation is defined primarily by the alignment of grains of chlorite and phengitic muscovite that bound and wrap recrystallized quartz grains, ilmenite, pyrite and arsenopyrite. Chlorite, which can form up to 30 vol.\% of the ultramylonite, is inter-grown with phengitic muscovite to form anastomosing, interconnected layers on millimetre- to micrometre-scales. Muscovite chemical compositions display high $\mathrm{Al}$ and $\mathrm{K}$ contents ( $\mathrm{Al}$ total $=4.6-5.3 \mathrm{apfu}$; $\mathrm{K}=1.7-2 \mathrm{apfu}$ ), low contents of $\mathrm{Ti}$ and $\mathrm{Na}(\mathrm{Ti}=0.01-0.13 \mathrm{apfu} ; \mathrm{Na}=0.03-0.10 \mathrm{apfu})$ and their $\mathrm{Mg}$ contents vary between 0.18 and 0.68 apfu (Table 1). They correspond to weakly phengitic muscovite and plot within the field of secondary muscovite in the ternary diagram Mg-Ti-Na of Miller et al. (1981) (El Amarani, 1994; El Arbaoui, 2018). Muscovite within the shear zones has higher Ba contents $(0.16<\mathrm{BaO} \mathrm{wt} \%<0.35)$ than in the undeformed counterparts $(\mathrm{BaO}<0.1 \mathrm{wt} \%)$. The $\mathrm{F}$ contents of muscovite $(<0.6 \mathrm{wt} \%)$ are lower than those of biotite $(<0.8 \mathrm{wt} \%)$.

The REE-bearing accessory minerals have undergone mechanical and chemical alteration during shearing. Coupled dissolution re-precipitation of accessory minerals is manifested by alignment of REE-bearing phases and often Fe-Ti oxides along the foliation plane (Fig. 7). Stringers of syntectonic monazite are developed along the cleavage planes of deformed chlorite and muscovite, replacing them in places (Fig. 7A). The microcrystalline, elongate morphology of monazite clearly differentiates it from the primary magmatic large and euhedral crystals observed in the undeformed rocks (Fig. 6B). Cerium oxide occurs locally in association with Fe- oxide or filling in shear-parallel fractures in the muscovitechlorite matrix (Fig. 7B). The mechanical alteration and re-organisation of the accessory minerals as a response to the shear stresses is manifested by fracturing and development of pressure shadows around resistant mineral phases, such as zircon and apatite (Fig. 7C). The ultramylonitized REE-enriched rocks are characterized by the presence of finely crystalline REE fluorocarbonates in addition to the secondary monazite-xenotime - dominated assemblage. The fluorocarbonates are typically associated with Ti and/or Fe oxides (Fig. 7 D-E). Primary xenotime is often armoured by quartz and retains its morphology and composition with no obvious signs of alteration. A secondary xenotime phase on the other hand, forms finely crystalline aggregates with $\mathrm{Th}+\mathrm{Ca} \pm \mathrm{REE}$ phosphate ( \pm silicate), apatite and secondary monazite (Fig. 7F-H). This is a common alteration assemblage of primary monazite. Euhedral rhombic crystals of the Th-rich phosphate ( \pm silicate) are present within the fine intergrowth with xenotime (Fig. $7 \mathrm{H}$ ), both inferred to be of secondary origin. Qualitative microanalysis revealed the presence of $\mathrm{Si}$ in a few data points, suggesting either a mixed phosphate-silicate phase or fine inclusions of silicate minerals within the complex intergrowth. In summary, the shear zones are characterized by grain size reduction of accessory minerals, their re-distribution/re-precipitation along the foliation plane, and the formation of secondary REE-bearing minerals that have developed during shearing.

\subsection{Temperature conditions}

The measured $\mathrm{Fe}^{2+} / \mathrm{Fe}^{3+}$ ratios of biotite in the Jebilet granitoids vary between 10 and 30 allowing El Amrani (1996) to estimate their temperature of crystallization to $750-800^{\circ} \mathrm{C}$ under low to moderate oxygen fugacities $\left(-16<\log \mathrm{f}\left(\mathrm{O}_{2}\right)<-13\right)$, at $2 \mathrm{~kb}$ pressure. Such temperatures are similar to the zircon saturation temperatures $\left(700-800{ }^{\circ} \mathrm{C}\right)$ (Essaifi et al., 2014) and to temperatures based on zircon typology (El Amrani, 1994). 
Chlorite displays homogeneous compositions with moderate to high $\mathrm{XFe}$ ratios $(0.66 \leq \mathrm{XFe} \leq$ $0.68)$ and $\mathrm{Al}$ contents $(\mathrm{Al}$ total $=5.3-5.6 \mathrm{apfu})$ and indicates temperatures between 350 and $380{ }^{\circ} \mathrm{C}$ (Bourdelle and Cathelineau, 2015). Such temperatures correspond to the low greenschist facies, i.e. to the regional metamorphism in the country rocks (Delchini et al., 2016; Essaifi et al., 2001a). The Si content of phengitic muscovite indicates a pressure between 2 and $3 \mathrm{~kb}$ (Massone and Schreyer, 1987).

The microstructural evolution of the Tabouchent shear zones, characterized by plastic deformation and recrystallization of quartz, brittle and reaction-assisted deformation of feldspars, is characteristic of low temperature deformation in shear zones (Gapais, 1989; Stünitz and Fitz Gerald, 1993). The shear zone network, which is consistent with the regional strain field, records the effects of the regional shortening on an intrusion thermally re-equilibrated with its host rocks.

\section{5. ${ }^{40} \mathrm{Ar} /{ }^{39} \mathrm{Ar}$ measurements and results}

In order to obtain the age of the low-grade ductile shear zone crosscutting the granodioritic pluton of Tabouchent, we have performed a preliminary age determination of the syn-kinematic phengitic muscovite developed in the mylonitic granodiorite. The dated sample JB14-02 was collected from a meter-scale shear zone crosscutting the granular granodiorite (Fig. 3). Bands dominated by white micas containing minor chlorite alternate with recrystallized quartz bands and define the mylonitic foliation of the sample. The non-coaxial structure of the mylonite is marked by $\mathrm{C} / \mathrm{S}$ structures and asymmetric crystallization tails around quartz porphyroclasts (Fig. 5F).

In the mylonitic granodiorite JB14-02, a white mica grain yielded a well-defined plateau age at $305.9 \pm 0.9 \mathrm{Ma}$ based on $86 \%$ of the ${ }^{39} \mathrm{Ar}$ released (steps 5, 6, 7, 8, 9 and 10; Fig. 8; Table 3). The experiment displays a slightly disturbed age spectra with younger ages at low-temperature steps suggesting a slight radiogenic argon loss.

The $305.9 \pm 0.9 \mathrm{Ma}$ obtained on the syntectonic white mica represents the age of the regional shearing tectonic event. It is consistent with the high-temperature shearing deformation that affected the leucogranite, which was dated by Rb/Sr dating at $297 \pm 9 \mathrm{Ma}, 296 \pm 6 \mathrm{Ma}$ (Tisserant, 1977), and $295 \pm$ $15 \mathrm{Ma}$ (Mrini et al., 1992). It is also consistent with the microstructural evolution observed in the sampled shear zone, which is characteristic of low-temperature shearing deformation that affected an intrusion thermally re-equilibrated with its host rocks. The emplacement age of this intrusion is $327 \pm 4 \mathrm{Ma}(\mathrm{Rb} / \mathrm{Sr}$ dating; Mrini et al., 1992), or even older, $358 \pm 7$ to $336 \pm 4$ Ma (U-Pb dating; Delchini et al., 2018). The preliminary Ar/Ar age indicates that the granodiorite was affected by shearing at least $20 \mathrm{Ma}$ after its emplacement and solidification.

\section{Whole rock geochemistry}

\subsection{Major and trace element geochemistry}

The undeformed granodiorites have homogeneous contents of $\mathrm{SiO}_{2}(68.12-70.98 \mathrm{wt} \%), \mathrm{Al}_{2} \mathrm{O}_{3}$ (14.56-15.65 wt\%), $\mathrm{TiO}_{2}(0.44-0.74 \%)$ and $\mathrm{P}_{2} \mathrm{O}_{5}(0.14-0.18 \mathrm{wt} \%)$. The $\mathrm{MgO}$ contents vary from 0.87 to $1.26 \mathrm{wt} \%$ and those of total $\mathrm{Fe}_{2} \mathrm{O}_{3}$ from 2.81 to $4.96 \mathrm{wt} \%$. $\mathrm{Na}_{2} \mathrm{O}$ and $\mathrm{K}_{2} \mathrm{O}$ vary respectively from 0.49 to $3.70 \mathrm{wt} \%$ and from 2.41 to $4.34 \mathrm{wt} \%$ while $\mathrm{CaO}$ varies from 0.4 to $1.58 \mathrm{wt} \%$ and $\mathrm{LOI}$ is between 1.66 
and $3.18 \mathrm{wt} \%$ (Table 2). Their contents of REE are consistent, as well as those of Ga (18-23 ppm), Zr (164-393 ppm), Nb (8-12 ppm), Y (45-50 ppm), and Th (16-22 ppm). They display weak variations in $\mathrm{Sr}, \mathrm{Rb}, \mathrm{Ba}$ and $\mathrm{Cs}$. These weak variations in chemical compositions indicate a low initial magmatic heterogeneity that can be explained by minor amounts of crystal fractionation (Bensalah, 1989; El Amrani, 1994). The undeformed granodiorites display a peraluminous affinity in the $A / N K$ vs $A / C N K$ diagram (Fig. 9), with the least altered sample (TB8) displaying the lowest $\mathrm{A} / \mathrm{CNK}$ value $(\mathrm{A} / \mathrm{CNK}=$ 1.27).

The concentrations of major and trace elements in the shear zones are compared to those of the undeformed counterparts in Figure 10. The bulk-rock composition of the various Tabouchent shear zone samples shows a much greater range than the variation in the composition of the undeformed granodiorite. For some elements (e.g. $\mathrm{Al}_{2} \mathrm{O}_{3}, \mathrm{TiO}_{2}$ ), the observed linear correlations with $\mathrm{SiO}_{2}$ can be explained by the quartz dissolution/precipitation effect, indicating that such elements remained relatively immobile during the alteration process. $\mathrm{Al}_{2} \mathrm{O}_{3}$ and $\mathrm{TiO}_{2}$ are enriched in rocks that have experienced a net loss of $\mathrm{SiO}_{2}$ and diluted in rocks that have experienced a net gain of $\mathrm{SiO}_{2}$, and their variations fit the modelled variations of concentrations due to quartz precipitation/dissolution (arrows in $\mathrm{SiO}_{2}$ vs. $\mathrm{Al}_{2} \mathrm{O}_{3}$ and $\mathrm{TiO}_{2}$ plots; Fig. 10). The concentration of the other elements reflects the dissolution of feldspar and the relative abundance of chlorite and muscovite within the shear zones. Muscovite-rich shear zones are enriched in $\mathrm{K}$ and depleted in $\mathrm{Ca}, \mathrm{Na}, \mathrm{Fe}, \mathrm{Mg}$ and $\mathrm{Mn}$ while the shear zones where chlorite is abundant are enriched in $\mathrm{Fe}, \mathrm{Mg}$ and $\mathrm{Mn}$ and depleted in $\mathrm{Ca}$ and $\mathrm{Na}$. The concentrations of some trace elements distinguish clearly between the shear zones (SZ) and their undeformed counterparts. This is the case for Ba with contents higher in all SZ (342-1550 ppm) than in the undeformed granodiorites (203-507 ppm), and $\mathrm{Sr}$ with contents lower in all SZ (10-62 ppm) than in their undeformed counterparts (32-215 ppm). $\mathrm{P}_{2} \mathrm{O}_{5}$ contents are typically lower in the $\mathrm{SZ}$ than in the undeformed granodiorites, which may indicate a limited dissolution of apatite. Tungsten has also higher contents in the SZ (24.6-31.4 ppm) than in the undeformed granodiorites (1.4-7.2 ppm). This is also true for $\mathrm{Sn}, \mathrm{Sb}$ and As, with respectively up to 950 ppm, $705 \mathrm{ppm}$ and $29 \mathrm{ppm}$ in the SZ while their contents in the undeformed counterparts are lower than $83 \mathrm{ppm}, 40 \mathrm{ppm}$ and $3.4 \mathrm{ppm}$, respectively. For other trace elements like $\mathrm{Ga}$, the observed variations can be explained by the dissolution/precipitation effect, indicating that the element may have been immobile during mylonitization of the granodiorite.

The concentrations of the REE in the shear zones show larger variations ( $\Sigma R E E=116-539 \mathrm{ppm})$ than in the undeformed counterparts ( $\Sigma R E E=170-239 \mathrm{ppm})$ (Fig. 11). Relatively to the undeformed and least altered granodioritic sample (TB8), the data indicate that REE were mobile in the majority of the samples ( $90 \%$ of 20 analysed deformed rocks), with most cases (89\%) showing a fractionation between LREE and HREE during alteration (Table 2). The comparison of the REE behaviour in the different shear zone profiles allows distinction of different types of SZ; (i) SZ with limited to no REE mobility (TB34-5 profile), (ii) SZ with local redistribution of REE from the outer parts to the inner parts of SZ (TB1516-17, TB25-26-27 and TB28-29 profiles), (iii) SZ with REE enrichment (TB22-23-24 profile), and (iv) SZ with LREE depletion (TB6-7, TB8-9, TB11-12, TB13-14, TB18-19 and TB20-21 profiles). Here, the 
patterns of REE mobility show either depletion in LREE relative to HREE, LREE less depleted relative to HREE, or REE depletion without any fractionation between LREE and HREE.

\subsection{Shear zones with limited to no REE mobility}

Isocon diagrams (Figs. 12-13), which compare the bulk-rock chemistry of rocks that have undergone changes in whole-rock compositions (Grant, 1986), are used to illustrate the mass transfer in the Tabouchent shear zones. In these diagrams, the deformed and altered rocks are compared to the least altered isotropic granodiorite (TB8 sample). The immobile elements $\mathrm{Al}$ and $\mathrm{Ti}$ form a straight line through the origin, and the line is known as the "isocon". The elements that experienced enrichment and depletion plot respectively above and below the isocon, and the slope of the isocon indicates the volume change that accompanied the transformation. If the slope of the isocon is one, then the concentrations of the immobile elements have not changed, and the transformation is isovolumetric. If the slope of the isocon is lower than one, then the transformation was accompanied by a volume gain. If the slope of the isocon is higher than one, then the transformation was accompanied by a volume loss.

In the shear zone where the REE were almost immobile, the Al-Ti isocon indicates a nearly isovolumetric transformation (Fig. 12A). The majority of the REE, as well as other trace and major elements, are located along or near the isocon indicating limited mobility. In contrast, some of the other elements plot far below or above the isocon indicating that they experienced strong depletion/enrichment during mylonitization. Among these elements, $\mathrm{Ca}, \mathrm{Na}$, and $\mathrm{Sr}$ were lost, and $\mathrm{Ba}, \mathrm{W}, \mathrm{As}, \mathrm{Sb}$, and $\mathrm{Sn}$ were gained. In contrast $\mathrm{K}, \mathrm{Fe}$, and $\mathrm{Mg}$ are located near the isocon indicating limited mobility. These changes are consistent with a local redistribution of $\mathrm{K}, \mathrm{Fe}$, and $\mathrm{Mg}$ caused by the destruction of feldspar and biotite and crystallization of phengitic muscovite and chlorite. During this process, $\mathrm{Ca}, \mathrm{Na}$ and $\mathrm{Sr}$ were transported out of the rock by the escaping fluids while W, As, Sb, and Sn were introduced by fluids. Ba is hosted by muscovite and $\mathrm{Sn}$ by cassiterite while $\mathrm{As}$ and $\mathrm{Sb}$ are most likely hosted by arsenopyrite. Tungsten is likely a trace component of other minerals, probably muscovite, which can host up to 500 ppm W (Eugster, 1985).

\subsection{Shear zones with REE enrichment}

The TB-24 ultramylonite, which illustrates coupled enrichment in both LREE and HREE, underwent about $200 \%$ volume gain due to quartz addition (blue line in Fig. 12B). Ta and $\mathrm{Nb}$ are located along the $\mathrm{Al}-\mathrm{Ti}$ isocon and can be considered as relatively immobile. This is reflected in the $\mathrm{Nb} / \mathrm{Ta}$ ratios, which are similar in the shear zones $(\mathrm{Nb} / \mathrm{Ta}=8.5-11.7)$ and their undeformed counterparts $(\mathrm{Nb} / \mathrm{Ta}=9.4-$ 10.8). Similarly, the location of $\mathrm{Zr}$ and $\mathrm{Hf}$ near the Al-Ti isocon suggests a relative immobility that is reflected in the $\mathrm{Zr} / \mathrm{Hf}$ ratios, which display similar variations in the shear zones (32.8-37.7) and the isotropic domains $(\mathrm{Zr} / \mathrm{Hf}=32.4-41)$. As in the shear zone where the $\mathrm{REE}$ are immobile, $\mathrm{Ca}, \mathrm{Na}$, and $\mathrm{Sr}$ were leached while $\mathrm{K}, \mathrm{Fe}$ and $\mathrm{Mg}$ remained relatively immobile, reflecting similar major mineral changes in the two types of shear zones. The behaviour of the major elements is explained by the mineralogical changes that occurred in the shear zone. The strong depletions in $\mathrm{Ca}$, $\mathrm{Na}$ and $\mathrm{Sr}$ result from the destruction of K-feldspar and plagioclase while the relative immobility of $\mathrm{K}, \mathrm{Fe}$ and $\mathrm{Mg}$ reflects the crystallization of phengitic muscovite and chlorite at the expense of biotite and feldspar. 


\subsection{Shear zones with REE depletion}

In all the shear zones with REE depletion (Fig 13), depletion in $\mathrm{Ca}, \mathrm{Na}$ and $\mathrm{Sr}$ reflect the breakdown of feldspar. Variations in $\mathrm{Fe}, \mathrm{Mg}, \mathrm{Mn}$ and $\mathrm{K}$ content reflect the variable replacement of biotite by phengitic muscovite and chlorite. All these shear zones are marked by the introduction of $\mathrm{W}, \mathrm{Sn}, \mathrm{Sb}$ and $\mathrm{As}$, whilst $\mathrm{Nb}, \mathrm{Ta}, \mathrm{Zr}$ and $\mathrm{Hf}$ remain relatively immobile.

REE depletion without a noticeable fractionation between LREE and HREE is illustrated by the TB19 mylonite (Fig. 13A). This is a constant volume transformation marked by the relative immobility of $\mathrm{Si}$, which is reflected in its location along the Al-Ti isocon. In the TB21 ultramylonite, the transformation is also isovolumetric, but the LREE are depleted relative to the HREE, which are almost immobile (Fig. 13B). The TB14 mylonite, which illustrates the case where HREE are depleted relative to LREE (Fig. 13C), underwent about $12 \%$ volume loss.

\subsection{Shear zones with local redistribution of REE}

The coexistence of opposite REE mass changes along a single shear zone profile, e.g. LREE loss in the TB16 mylonite versus LREE gain in the TB17 ultramylonite (Fig. 14), suggest a local redistribution of REE. Enrichment of the inner parts of shear zones in elements removed from the outer parts of shear zones is consistent with a meter-scale transport of the REE from the shear zone margin to the shear zone core. Such a local redistribution of REE has also been observed in other geological contexts where fluid flow was highly channelized. Examples include the greenschist-facies shear zones of the Mont Blanc granite (Rolland et al., 2003) and the eclogite-facies alteration assemblage in the subduction complex of the Tienshan mountains (Beinlich et al., 2010).

In summary, all the shear zones are characterised by losses in $\mathrm{Ca}, \mathrm{Na}$ and $\mathrm{Sr}$, which result from the destruction of $\mathrm{K}$-feldspar and plagioclase while the mobility of $\mathrm{K}, \mathrm{Fe}$ and $\mathrm{Mg}$ reflects the relative abundance of phengitic muscovite and chlorite that crystallize at the expense of feldspar and biotite. The linear correlation coefficients for both LREE and HREE trends on the isocon diagrams are high $\left(\mathrm{R}^{2}>0.9\right)$ in both REE depletion or enrichment cases. The behavior of some trace elements is similar to that of the REE. This is the case for $\mathrm{Y}$, which is fractionated in the same way as the HREE. Accordingly, the Y/Ho ratio, which ranges from 25.1 to 28.8 in the shear zones and from 26.6 to 27.9 in their undeformed counterparts, remained close to the chondritic ratio of $27.7 \pm 2.7$ (Bau, 1996). In contrast, Ba is gained in all the shear zones while P is lost in almost all the SZ. The metals $\mathrm{W}, \mathrm{Sn}, \mathrm{Sb}$, and As are enriched in all the shear zones.

\section{Discussion}

\subsection{Mineralogical control on REE mass transfer}

The behavior of REE in the Tabouchent shear zones is strongly decoupled from that of other elements. There is also a decoupling between LREE and HREE during the alteration process, and $\mathrm{Y}$ was fractionated in the same way as HREE. The REE variation was not caused by volume changes related to shearing because the REE trends are well below or above the isocons. The decoupling between LREE and HREE is unrelated to the intensity of strain because it occurred in both the mylonites and the 
ultramylonites (Figs. 12,13). The depletion/enrichment in REE is unrelated to the nature of the main crystallizing silicate assemblage, since all the shear zones have the same metamorphic assemblage of quartz + muscovite \pm chlorite and are characterized by losses in $\mathrm{Na}$ and $\mathrm{Ca}$ and gains in $\mathrm{K}$ and volatiles. The behaviors of REE in the Tabouchent SZ are likely to be related to the stability and relative abundance of the REE-bearing phases. The REE in igneous rocks are mostly hosted by accessory minerals, and mass-balance calculations indicate that their whole-rock REE budget is accounted for by the composition and proportion of these accessory minerals (Bea, 1996; Ward et al., 1992). In peraluminous granites, most of the LREE reside within monazite while the HREE reside essentially within xenotime, apatite and zircon (Bea, 1996). In the Tabouchent intrusion, the main REE-bearing accessory minerals are zircon, monazite, apatite, and xenotime. These minerals in shear zones display significant size reduction, re-distribution/re-precipitation along the foliation plane, and alteration into secondary REE-bearing minerals that have developed during shearing.

Hydrothermal remobilization of REE in granitic rocks is related to dissolution/re-precipitation of accessory minerals, which is interpreted to be a function of the fluid composition and PT conditions (Dongen et al., 2010; Förster, 2000; Leroy and Turpin, 1988; Rolland et al., 2003). In order to determine the relationship between the REE content and the dissolution/re-precipitation of the accessory minerals, the total REE content is presented versus the content of each REE to test whether the bulk of the REE is hosted in apatite, zircon, xenotime, or monazite (Fig. 15). There is a high positive linear correlation between the total REE content and the contents of the LREE La, Ce, Pr, Nd, Sm and Gd. This reflects the strong control exerted by monazite on the LREE budget in both the undeformed granodiorites and the crosscutting shear zones. A positive correlation between the total REE content and the contents of the HREE is not evident (e.g. Yb and Lu; Fig. 15), but the mass changes for HREE correlate positively with the $\mathrm{Y}$ mass changes (Fig. 16A-G), and there is also a positive correlation between $\mathrm{Y}$ and $\mathrm{REE}_{\max }$ (Fig. 16H). Thus HREE mobilisation in the SZ did not occur without mobilisation of Y. This is consistent with the fact that $Y$ was fractionated in the same way as HREE and indicates that the main control of the HREE budget in the shear zones was exerted by xenotime. Consequently, it seems that every case of fractionation of LREE relative to HREE can be related to the preferential dissolution or precipitation of monazite and xenotime. This is supported by petrographic evidence that shows prominent textural modifications to monazite and xenotime, except when they are enclosed in quartz, where they remain largely intact. Whilst residual apatite and zircon domains are still observed in the shear zones, most monazite crystals appear to have undergone complex, coupled dissolution-precipitation processes. Namely, fine-grained Th, $(\mathrm{Ca} \pm \mathrm{REE})$ phosphate/silicate in association with interstitial Y phosphate and apatite have been commonly observed in domains that are inferred to be monazite originally (Fig. 7F$\mathrm{H})$. These are likely to be the sites of dissolution of primary monazite and its re-precipitation into syntectonic monazite mediated by metamorphic fluids. This process is in agreement with the low crystallization temperatures of the metamorphic monazite $\left(\mathrm{ca} 350^{\circ} \mathrm{C}\right.$ ) where $\mathrm{Th}, \mathrm{Ca}$ and $\mathrm{Y}$ are incompatible in the monazite structure and combine with $\mathrm{Si}$ and $\mathrm{P}$ to form Th-silicate, apatite and xenotime (Rasmussen and Muhling, 2007, 2009). The syntectonic monazite and xenotime have grown to form stringers along the foliation plane, locally replacing the host mineral and have also been observed dispersed in softer micaceous-chlorite matrix; with euhedral crystals present in places (Fig. 7). The 
growth of xenotime associated with $\mathrm{P}$ and $\mathrm{Y}$ metasomatism and the consequent enrichment in HREE during fluid infiltration has also been described in greenschist to amphibolite facies metamorphosed carbonate rocks of the Wepawaug Schist, USA (Ague, 2003).

Petrographic analysis also revealed the presence of REE fluorocarbonates in association with Ti oxide and $\mathrm{Fe} \pm \mathrm{Cu}$ oxide, predominantly in the REE-enriched ultramylonitized samples (Fig. 7 D-E). Whilst the presence of fluorine in the fluids can be explained by the dissolution of primary magmatic minerals (mica, fluorapatite); the presence of carbonate minerals requires an influx of $\mathrm{CO}_{2}$-rich fluids at some point during the evolution of the shear zone. $\mathrm{CO}_{2}$-rich fluids were observed in fluid inclusions in the nearby Roc Blanc deposit (Essarraj et al., 2017) and in the pegmatites dykes crosscutting schists less than $5 \mathrm{~km} \mathrm{NE}$ of the Roc Blanc mine (Bastoul, 1992).

The mobilisation of REE in the shear zones is also supported by the presence of fine crystalline Ce oxide in shearing-related cracks and fissures. Ce oxide has also been observed associated with secondary Fe oxide; and in this assemblage, both oxide phases have been remobilized (Fig. 7). The secondary iron oxide has likely formed as a result of dissolution of magmatic ilmenite. Whilst Ti crystallised locally as Ti oxide (likely rutile), iron has likely been oxidized and mobilized. This could be facilitated by the presence of chloride complexes that impact on the hydrothermal transport chemistry of $\mathrm{Fe}^{2+}$ and $\mathrm{Fe}^{3+}$, in particular (Seward et al., 2013). It is also known that transport chemistry of $\mathrm{REE}^{3+}$ and $\mathrm{Ce}^{4+}$ is different, and that preferential immobilization of Ce by oxidation is well documented in a variety of environments and conditions (Loges et al., 2012). Although the transport chemistry of cerium is complex, it is reasonable to infer that the observed Ce oxide in the shear zone originated from dissolution of magmatic monazite, oxidation of the released $\mathrm{Ce}^{3+}$ to $\mathrm{Ce}^{4+}$ and localized immobilization as cerianite. Both phases have been observed in close proximity, suggesting short distance transport of $\mathrm{Ce}^{4+}$.

\subsection{Controls on the REE mobility in the Tabouchent shear zones}

At least in some geological environments, the REE are clearly soluble and mobile in aqueous solutions, and their mobility is a function of the fluid composition and PT conditions (e.g. Wood, 1990). The Tabouchent shear zones present a silicate mineral assemblage consisting of quartz + muscovite \pm chlorite, and correspond to low temperature $\left(350-380^{\circ} \mathrm{C}\right)$ shear zones formed at least ca. $20 \mathrm{Ma}$ after emplacement and thermal re-equilibration of the granodioritic intrusion. As all the shear zones formed at similar PT conditions, the REE mobility should be related to fluid chemistry, especially to the potential ligands present in the fluids, because REE are known to be transported in fluids in the preferential form of complexes. Consequently, the complexing anion in the fluids is one of the key factors controlling the mobility of REE (e.g. Haas et al., 1995).

In the Jebilet massif, mobilization of REE and $\mathrm{P}$ in the Tabouchent shear zones contrast with their immobility in the Kettara shear zones where, in addition to $\mathrm{Al}$ and Ti, $\mathrm{P}$ was also immobile (Essaifi et al., 2004). This confirms the broad correlations observed between REE and P mobility, and suggesting REE transport by P complexes, or REE and P transport together by some other complexing agent (Ague, 2017). The elements dissolved in the fluid are reflected in the composition of the minerals precipitated in the shear zones and associated veins. Apatite, monazite and xenotime indicate the presence of 
phosphates, while the precipitation of pyrite in the veins and shear zones clearly indicates the presence of sulfide complexes in the fluid. Further, the presence of fluorine in apatite and the precipitation of Frich REE minerals in some $\mathrm{SZ}$ as well as the presence of fluorite and quartz-tourmaline veins and nodules indicate that $\mathrm{F}$ and $\mathrm{B}$ were also present in the fluids. Finally, the crystallization of calcite in the veins and the precipitation of $\mathrm{CO}_{2}$-rich REE-minerals in some shear zones require the presence of carbonate complexes in the fluids.

The main reaction that transformed the granodiorite into the ultramylonites at Tabouchent is muscovitization of feldspar. Such a reaction consumes $\mathrm{H}^{+}$ions and requires an acidic fluid composition (Charoy, 1979; Crerar and Barnes, 1976; Wibberley and McCaig, 2000). The breakdown of alkali feldspar into muscovite was also accompanied by leaching of $\mathrm{Ca}, \mathrm{Na}$ and $\mathrm{Sr}$ from the mylonitized rocks while $\mathrm{K}$ and $\mathrm{Ba}$ were gained. The leaching of $\mathrm{Ca}$ that accompanied mylonitization of the granodiorite indicates that the hydrothermal fluids have exceptionally low contents of $\mathrm{Ca}$. Such Ca-poor fluids are able to mobilize HFSE in F-rich geological environments even at low temperatures (Salvi and WilliamsJones, 1996).

\subsection{Metallogenic implications}

The bulk-rock $\mathrm{Nb} / \mathrm{Ta}$ and $\mathrm{Zr} / \mathrm{Hf}$ ratios are considered as markers of both magmatic evolution (Linnen and Keppler, 1997, 2002) and magmatic-hydrothermal interactions in peraluminous granites (Bau, 1996; Dostal et al., 2015). They decrease with fractional crystallization and display different values in barren and ore-bearing peraluminous granites. The ore-bearing peraluminous granites typically have $\mathrm{Nb} / \mathrm{Ta}<5$, whereas barren peraluminous granites have $\mathrm{Nb} / \mathrm{Ta}>5$. Moreover, the peraluminous granites associated with $\mathrm{Sn}, \mathrm{W}$, and/or $\mathrm{U}$ deposits have $\mathrm{Zr} / \mathrm{Hf}>18$ while the rare metals granites have $\mathrm{Zr} / \mathrm{Hf}<18$ (Ballouard et al., 2016). The bulk-rock $\mathrm{Nb} / \mathrm{Ta}$ and $\mathrm{Zr} / \mathrm{Hf}$ ratios in the Tabouchent intrusion, which have not been modified by fluid-rock interaction in the shear zones, are higher in the granodiorite ( $32<\mathrm{Zr} / \mathrm{Hf}$ $<40 ; 9<\mathrm{Nb} / \mathrm{Ta}<12)$ than in the leucogranite and the associated greisen $(16<\mathrm{Zr} / \mathrm{Hf}<22 ; 2<\mathrm{Nb} / \mathrm{Ta}<$ 4). In the $\mathrm{Zr} / \mathrm{Hf} \mathrm{vs} \mathrm{Nb} / \mathrm{Ta}$ diagram (Fig. 17A), the leucogranite and associated greisen plot in the field of ore-bearing granites while the granodioritic samples and associated shear zones plot within the field of barren granites. The $\mathrm{Zr} / \mathrm{Hf}$ ratios of the leucogranite and associated greisen are also consistent with $\mathrm{Sn}$, W-bearing granites and rare metals granites.

The tetrad effect represents the intra-REE fractionation observed in the REE patterns of highly fractionated granites and in hydrothermal precipitates, and reflects a selective complexation of REE during the interaction of granitic melts with F-rich and Cl-rich aqueous fluids (Bau, 1996; Irber, 1999; Monecke et al., 2002). The degree of the tetrad effect can be quantified using the parameter $\mathrm{TE}_{1-3}$, which measures the deviation of the first and the third tetrad of the granite REE pattern from a hypothetical tetrad-free pattern (Irber, 1999):

$$
\begin{aligned}
& \mathrm{TE}_{1-3}=(\mathrm{t} 1 * \mathrm{t} 3)^{0.5} \\
& \text { with } \mathrm{t} 1=\left(\mathrm{Ce} / \mathrm{Ce}^{\mathrm{t}} * \mathrm{Pr} / \mathrm{Pr}^{\mathrm{t}}\right)^{0.5} \\
& \mathrm{t} 3=\left(\mathrm{Tb} / \mathrm{Tb}^{\mathrm{t}} * \mathrm{Dy} / \mathrm{Dy}^{\mathrm{t}}\right)^{0.5} \\
& \text { with } \mathrm{Ce} / \mathrm{Ce}^{\mathrm{t}}=\mathrm{Ce}_{\mathrm{cn}} /\left(\mathrm{La}_{\mathrm{cn}}{ }^{2 / 3} * \mathrm{Nd}_{\mathrm{cn}}{ }^{1 / 3}\right)
\end{aligned}
$$


$\operatorname{Pr} / \operatorname{Pr}^{\mathrm{t}}=\operatorname{Pr}_{\mathrm{cn}} /\left(\operatorname{La}_{\mathrm{cn}}{ }^{1 / 3} * \mathrm{Nd}_{\mathrm{cn}}{ }^{2 / 3}\right)$

$\mathrm{Tb} / \mathrm{Tb}^{\mathrm{t}}=\mathrm{Tb}_{\mathrm{cn}} /\left(\mathrm{Gd}_{\mathrm{cn}}{ }^{2 / 3} * \mathrm{Ho}_{\mathrm{cn}}{ }^{1 / 3}\right)$

$\mathrm{Dy} / \mathrm{Dy}^{\mathrm{t}}=\mathrm{Dy}_{\mathrm{cn}} /\left(\mathrm{Gd}_{\mathrm{cn}} 1 / 3 * \mathrm{Ho}_{\mathrm{cn}}{ }^{2 / 3}\right)$

$\mathrm{Ln}_{\mathrm{cn}}=$ chondrite-normalized lanthanide concentration

The results show that the leucogranitic samples and associated greisen not only present low $\mathrm{Nb} /$ Ta ratios, but also a significant tetrad effect $\left(\mathrm{TE}_{1-3}>=1.1\right.$; Fig. 17B). In contrast, the tetrad effect is absent in the undeformed granodioritic samples, which have low $\mathrm{TE}_{1-3}$ values (1.01-1.02). On the other hand, the deformed granodioritic samples display an increasing degree of tetrad effect that reaches or even exceeds the degree of the tetrad effect of the leucogranite and associated greisen. These results confirm on one side that the tetrad effect can be introduced during hydrothermal alteration (Monecke et al., 2007), and on the other side that the tetrad effect in the SZ most likely results from the interaction of the granodiorite with hydrothermal fluids related to the leucogranite.

The gains in Sn, W, Sb, and As observed in all the shear zones indicate that the fluid was metalbearing. Whilst $\mathrm{Sn}$ is associated with the formation of cassiterite, the $\mathrm{W}$, As and $\mathrm{Sb}$ contents in the shear zones are not as clearly accounted for, although $\mathrm{As}$ and $\mathrm{Sb}$ are probably due to the presence of arsenopyrite, and W to muscovite, which can host up to $500 \mathrm{ppm}$ W (Eugster, 1985). Importantly, the enrichments observed in such metals are consistent with flow of a magmatic-hydrothermal fluid exsolved from the ore-bearing leucogranite. This is supported by the high temperature deformation of the leucogranite and by the retrogression of andalusite and cordierite, together with a significant tourmalinization of the host rocks indicating extensive boron mobilization in the leucogranitic aureole (Le Corre and Saquaque, 1987). Muscovitization of the granodiorite along the shear zone network, and greisenization of the leucogranite in the Bramram cupola are thus similar processes related to interaction between crystallized granites and acidic magmatic fluids (Pirajno, 2013). Interestingly, losses in Ca and $\mathrm{Na}$ and gains in $\mathrm{K}$ and volatiles appear to be typical for metasomatized quartzo-feldspathic ductile fault zones and are explained as the result of fluid flow in the direction of decreasing temperature (Dipple and Ferry, 1992; Streit and Cox, 1998). Accordingly, the chemistry of the fluids that circulated in the Tabouchent shear zones is consistent with upflow of magmatic-hydrothermal fluids exsolved from a leucogranitic body located below the Tabouchent granodioritic intrusion (Fig. 18).

The greisen-related hydrothermal system and the associated Sn-W mineralization in the Central Jebilet pluton was developed on a wide region on each side of the Marrakech shear zone (Fig. 1). The development of spotted schists towards the Sidi Bou Othmane region, together with a pegmatite dyke swarm suggests that the intrusion of the leucogranite and associated hydrothermal system may cover the whole area. This region is also characterized by the development of skarns, which are locally mineralized in graphite, chalcopyrite, sheelite, molybdenite, and fluorite \pm cassiterite (Bastoul, 1983; El Mostadi, 1992 ; Huvelin, 1977). Interestingly, there is a metal zonation in the country rocks around the Tabouchent intrusion with evolution from a proximal $\mathrm{Cu}-\mathrm{Au}$ vein mineralization in the Jbel Haimer deposit to a distal $\mathrm{Pb}-\mathrm{Zn}-\mathrm{Ag}-\mathrm{Au}$ vein mineralization in the Roc Blanc deposit (Fig. 2A). Such a zonation is consistent with an open greisen-hydrothermal system related to the emplacement of the S-type Variscan leucogranites (Fig. 18). This interpretation contrasts with the recent investigations on the Roc Blanc deposit, which 
relate its genesis to either metamorphic dehydration and $\mathrm{CO}_{2}$ devolatilization during exhumation of the Jebilet massif (El Arbaoui et al., 2019), or to a large-scale hydrothermal circulation of basinal brines during the Triassic opening of the Central Atlantic Ocean (Essarraj et al., 2017). The $\mathrm{Sr}$ and the $\mathrm{Pb}$ isotopic data of the Roc Blanc deposit (Chouhaidi, 1986; El Arbaoui et al., 2019), and the Tabouchent granodiorite (Mrini et al., 1992) are consistent with a magmatic-hydrothermal origin of the mineralization. The C, O and H stable isotopic data (El Arbaoui et al., 2019; Essarraj et al., 2017) indicate however that the Roc Blanc mineralization originated from a metamorphic fluid-circulation. Consequently, it seems that the hydrothermal fluid circulations in the Tabouchent Shear Zone have mixed the magmatic with the metamorphic fluids to scavenge and transport metals, and the magmaticmetamorphic model appears to be the more likely.

\section{Conclusion}

A preliminary ${ }^{40} \mathrm{Ar} /{ }^{39} \mathrm{Ar}$ dating on white mica allowed us to date the regional shear zone that cuts across the Tabouchent granodiorite at $305.9 \pm 0.9 \mathrm{Ma}$ by ${ }^{40} \mathrm{Ar} /{ }^{39} \mathrm{Ar}$ dating. The tectonic event was contemporaneous with emplacement of S-type peraluminous leucogranites that intrude the granodiorite, which was emplaced at least $20 \mathrm{Ma}$ earlier. Acidic magmatic fluids were most likely exsolved from the leucogranite while the granodiorite was undergoing a low temperature shearing marked by brittle deformation of feldspar and recrystallization of quartz. The deformation-enhanced permeability allowed the exsolved fluids to percolate the shear zones resulting in the breakdown of feldspar and biotite to muscovite + chlorite. Fluid-rock interaction in the shear zones resulted in an extensive mobilization of REE and other major and trace elements. Typical losses in $\mathrm{Na}$ and $\mathrm{Ca}$ and gains in $\mathrm{K}$ and volatiles occurred consistently with a down temperature fluid flow. The changes in the REE concentrations are decoupled from the major chemical changes. They are marked by fractionation between LREE and HREE, and by a variety of behaviors including little or no REE mobility, LREE mobility and HREE mobility. The alteration of magmatic accessory REE-bearing phases, predominantly monazite, followed by the reprecipitation of syntectonic monazite, xenotime, $\mathrm{Th}+\mathrm{Ca} \pm \mathrm{REE}$ phosphate/silicate, Ce oxide and REE fluorocarbonates, appear to be the main mineralogical changes that control the REE fractionation and the REE mass transfer.

The shear zones are typically enriched in As, W, Sn and Sb, and thus the hydrothermal alteration along the shear zones is similar to the greisenization and associated Sn-W mineralization that affected the leucogranite. As the shear zones are interconnected allowing fluid flow at a regional scale, the metal zonation observed around the pluton from a proximal $\mathrm{Cu}-\mathrm{Au}$ mineralization to $\mathrm{Ag}-\mathrm{Pb}-\mathrm{Zn}-\mathrm{Au}$ mineralization is inferred to be related to the greisen-hydrothermal system associated with emplacement of the S-type leucogranites.

\section{Acknowledgements}

This work has received a financial support from the CNRST through the project URAC 43. AML and KMG publish with the permission of the Executive Director, British Geological Survey (UKRI). Dr Jeremy Rushton (BGS) is acknowledged for insightful input during SEM data acquisition and Ms Eimear 
Deady (BGS) for undertaking BGS internal revision of the manuscript. We wish to thank J.L. Lagarde for comments on an earlier draft of the manuscript. The constructive reviews of S. Salvi and Y. Rolland improved presentation of data and discussion; they were highly appreciated.

\section{References}

Aarab, E.M., Beauchamp, J., 1987. Le magmatisme carbonifère pré-orogénique des Jebilet centrales (Maroc). Précisions pétrographiques et sédimentaires. Implications géodynamiques. C. R. Acad. Sci. Paris II, 304, 169-174.

Ague, J.J., 2003. Fluid infiltration and transport of major, minor, and trace elements during regional metamorphism of carbonate rocks, Wepawaug Schist, Connecticut, USA. American Journal of Science $303,753-816$.

Ague, J.J., 2017. Element mobility during regional metamorphism in crustal and subduction zone environments with a focus on the rare earth elements (REE). American Mineralogist 102, 1796-1821.

Bailey, C.M., Simpson, C., De Paor, D.G., 1994. Volume loss and tectonic flattening strain in granitic mylonites from the Blue Ridge province, central Appalachians. J. Struct. Geol. 16, 1403-1416.

Ballouard, C., Poujol, M., Boulvais, P., Branquet, Y., Tartèse, R., Vigneresse, J.-L., 2016. Nb-Ta fractionation in peraluminous granites: A marker of the magmatic-hydrothermal transition. Geology 44, 231-234.

Bastoul, A., 1983. Etude des fluides carbo-azotés associés au métamorphisme de contact des schistes noirs sur l'exemple des Jebilet Centrales (Maroc). Unpub Ph.D. Thesis, Nancy I Univ.

Bau, M., 1996. Controls on the fractionation of isovalent trace elements in magmatic and aqueous systems: evidence from Y/Ho, Zr/Hf, and lanthanide tetrad effect. Contrib Mineral Petrol 123, 323-333.

Bea, F., 1996. Residence of REE, Y, Th and U in Granites and Crustal Protoliths; Implications for the Chemistry of Crustal Melts. Journal of Petrology 37, 521-552.

Beauchamp, J., Izart, A., Piqué, A., 1991. Les bassins d'avant pays de la chaîne hercynienne au Carbonifère inférieur. Can. J. Earth Sci. 28, 2024-2041.

Beinlich, A., Klemd, R., John, T., Gao, J., 2010. Trace-element mobilization during Ca-metasomatism along a major fluid conduit: Eclogitization of blueschist as a consequence of fluid-rock interaction. Geochimica et Cosmochimica Acta 74, 1892-1922.

Bensalah, M.K., 1989. Etude pétrographique, géochimique et structurale des massifs granitiques de Bamega-Tabouchennt-Bramram et Ouled Ouaslam (Jebilet, Maroc). Unpub Ph.D. Thesis, Univ. Marrakech.

Bordonaro, M., Gaillet, J.L., Michard, A., 1979. Le géosynclinal carbonifère sud-mésetien dans les jebilet (Maroc) : une corrélation avec la province pyriteuse du Sud de l'Espagne. C. R. Acad. Sci. Paris D 288, 1371-1374.

Bos, B., Spiers, C.J., 2001. Experimental investigation into the microstructural and mechanical evolution of phyllosilicate-bearing dault rock under conditions favouring pressure solution. Journal of Structural Geology 23, 1187-1202.

Bouloton, J., 1992. Mise en évidence de cordiérite héritée des terrains traversés dans le pluton granitique des Oulad Ouaslam (Jebilet, Maroc). Can. J. Earth Sci. 29, 658-668. 
Boummane, M.H., Olivier, P., 2007. The Oulad Ouaslam Variscan granitic pluton (Jebilet Massif, Southwestern Moroccan Meseta): a forcibly emplaced laccolithic intrusion characterized by its magnetic and magmatic fabrics. Journal of African Earth Sciences 47, 49-61.

Bourdelle, F., Cathelineau, M., 2015. Low-temperature chlorite geothermometry: a graphical representation based on a T-R2+-Si diagram. European Journal of Mineralogy, 27, 617-626.

Budzyn, B., Harlov, D.E., Williams, M.L., Jercinovic, M.J., 2011. Experimental determination of stability relations between monazite, fluorapatite, allanite, and REE-epidote as a function of pressure, temperature, and fluid composition. American Mineralogist 96, 1547-1567.

Carignan, J., Hild, P., Mevelle, G., Morel, J., Yeghicheyan, D., 2001. Routine analyses of trace elements in geological samples using flow injection and low pressure on-line liquid chromatography coupled to ICP-MS: a study of geochemical reference materials BR, DR-N, UB-N, AN-G and GH. Geostandards Newsletter 25, 187-198.

Charoy, B., 1979. Déinition et importance des phénomènes deutériques et des fluides associés dans les granites. Conséquences méallogéniques. Doctorat d'Etat.

Chemesseddoha, A., 1986. Cisaillement ductile et granites syntectoniques dans les Jebilet centrales : l'exemple du pluton hercynien des Oulad Ouaslam (massif des Jebilet, méseta sud marocaine). Unpub Ph.D. Thesis, Univ. Rennes I.

Chen, W.T., Zhou, M.-F., 2017. Hydrothermal alteration of magmatic zircon related to NaCl-rich brines: Diffusion-reaction and dissolution-reprecipitation processes. American Journal of Science 317, 177-215.

Chouhaïdi, M.Y., 1986. Contribution à l'étude pétrographique, géochimique et métallogénique des minéralisations argentifères des Jebilet centrales (l'exemple de Roc Blanc). Unpub Ph.D. Thesis, Univ. Nancy.

Condie, K.C., Sinha, K., 1996. Rare earth and other trace element mobility during mylonitization: a comparison of the Brevard and Hope Valley shear zones in the Appalachian Mountains, USA. J. metamorphic Geol. 14, 213-226.

Crerar, D.A., Barnes, H.L., 1976. Ore solution chemistry V. Solubilities of chalcopyrite and chalcocite assemblages in hydrothermal solution at $200^{\circ} \mathrm{C}$ to $350^{\circ} \mathrm{C}$. . Econ. Geol. 71, 772-794.

Delchini, S., Lahfid, A., Lacroix, B., Baudin, T., Hoepffner, C., Guerrot, C., Lach, P., Saddiqi, O., Ramboz, C., 2018. The geological evolution of the Variscan Jebilet massif, Morocco, inferred from new structural and geochronological analyses. Tectonics 37, 4470-4493.

Delchini, S., Lahfid, A., Plunder, A., Michard, A., 2016. Applicability of the RSCM geothermometry approach in a complex tectono-metamorphic context: The Jebilet massif case study (Variscan Belt, Morocco). Lithos 256-257, 1-12.

Dipple, G.M., Ferry, J.M., 1992. Metasomatism and fluid flow in ductile fault zones. Contrib. Mineral. Petrol. 112, 149-164.

Dongen, M.V., Weinberg, R.F., Tomkins, A.G., 2010. REE-Y, Ti, and P remobilization in magmatic rocks by hydrothermal alteration during $\mathrm{Cu}$-Au deposit formation. Economic Geology 105, 763-776.

Dostal, J., Keppie, J.D., Hamilton, M.A., Aarab, E.M., Lefort, J.P., Murphy, J.B., 2005. Crustal xenoliths in Triassic lamprophyre dykes in western Morocco: tectonic implications for the Rheic Ocean suture. Geological Magazine 142, 159-172.

Dostal, J., Kontak, D.J., Gerel, O., Shellnutt, J.G., Fayek, M., 2015. Cretaceous ongonites (topaz-bearing albite-rich microleucogranites) from Ongon Khairkhan, Central Mongolia: products of extreme magmatic fractionation and pervasive metasomatic fluid: rock interaction. Lithos 236, 173-189. 
El Amrani, E.H.I.-E., 1994. Genèse et mise en place des granitoïdes peralumineux à biotite et cordiérite des Jebilet centrales (Maroc). Unpub Ph.D. Thesis, Mohamed V Univ., Rabat.

El Amrani, E.H.I.-E., 1996. Petrogenèse des granitoïdes peralumineux des Jebilet centrales (Maroc) approche par l'étude des enclaves. Bull. Inst. Sei., Rabat, 20, 1-23.

El Arbaoui, A., 2018. Métallogénie des minéralisations polymétalliques argento-aurifères du district minier de Roc Blanc (Massif hercynien des Jebilet, Maroc). Unpub Ph.D. Thesis, Cadi Ayyad University, Morocco.

El Arbaoui, A., Bouabdellah, M., Wafik, A., Klügel, A., Jébrak, M., Castorina, F., Lowry, D., Lecumberri-Sanchez, P., Essaifi, A., Maacha, L., 2019. The Roc Blanc orogenic Pb-Zn-Ag-Au deposit (Morocco): a product of metamorphic dehydration and $\mathrm{CO} 2$ devolatilization during exhumation of the Variscan Jebilet massif. Mineralium Deposita 54, 437-458.

El Hassani, A., 1982. Contribution à la connaissance de l'évolution structurale et métamorphique du segment hercynien des Jebilet centrales (région de Sidi Bou Othmane). Bulletin de l'Institut Scientifique (Rabat), 1-43.

El Mostadi, A., 1992 Etude géologique, pétrographique et gîtologique des skarns minéralisés en scheelite et cassitérite du secteur de Sidi Bou Othmane (Jebilet centrale, Maroc). Unpub Ph.D. Thesis, Cadi Ayyad University Marrakech, p. 220 p.

Essaifi, A., 1995. Relations entre magmatisme-déformation et altération hydrothermale: l'exemple des Jebilet centrales (Hercynien, Maroc). Mémoires Géosciences Rennes 66, 340.

Essaifi, A., Ballèvre, M., Marignacc, C., Capdevila, R., 2001a. Découverte et signification d'une paragenèse à ilménite zincifère dans les métapélites des Jebilet centrales (Maroc). C. R. Acad. Sci. Paris 33, 381-388.

Essaifi, A., Capdevila, R., Fourcade, S., Lagarde, J., Ballèvre, M., Marignac, C., 2004. Hydrothermal alteration, fluid flow and volume change in shear zones: the layered mafic-ultramafic Kettara intrusion (Jebilet Massif, Variscan belt, Morocco). Journal of Metamorphic Geology 22, 25-43.

Essaifi, A., Lagarde, J.L., Capdevila, R., 2001b. Deformation and displacement from shear zone patterns in the Variscan upper crust, Jebilet, Morocco. Journal of African Earth Sciences 32, 335-350.

Essaifi, A., Potrel, A., Capdevila, R., Lagarde, J.L., 2003. Datation U-Pb : âge de mise en place du magmatisme bimodal des Jebilet centrales (chaîne varisque, Maroc). Implications géodynamiques.

$\mathrm{U}-\mathrm{Pb}$ dating: emplacement age of the bimodal magmatism of central Jebilet (Variscan Belt, Morocco). Geodynamic implications. Comptes Rendus Geoscience 335, 193-203.

Essaifi, A., Samson, S., Goodenough, K.M., 2014. Geochemical and Sr-Nd isotopic constraints on the petrogenesis and geodynamic significance of the Jebilet magmatism (Variscan Belt, Morocco). Geological Magazine 151, 666-691.

Essarraj, S., Boiron, M., Cathelineau, M., Tarantola, A., Leisen, M., Hibti, M., 2017. Mineralogy and ore fluid chemistry of the Roc Blanc Ag deposit, Jebilet Hercynian massif, Morocco. J Afr Earth Sci 127, 175-193.

Eugster, H.P., 1985. Granites and hydrothermal ore deposits: a geochemical framework. Geological Magazine 49, 7-23.

Fontan, F., Huvelin, P., Orliac, M., Permingeat, F., I976. La ferrisicklerite des pegmatites de Sidi Bou Othmane (Jebilet, Maroc) et le groupe des mineraux a structure de triphylite. Bull. Soc. fr. Mineral. Cristallogr. 99, 274-286.

Förster, H.-J., 2000. Cerite-(ce) and thorian synchysite-(ce) from the niederbobritzsch granite, erzgebirge, germany: implications for the differential mobility of the LREE and Th during alteration. The Canadian Mineralogist 38,,67-79. 
Gapais, D., 1989. Les orthogneiss. Structures, mécanismes de déformation et analyse cinématique. Mém. Docs. CAESS, Rennes 28, 377.

Geisler, T., Pidgeon, R.T., Kurtz, R., Wvan Bronswijk, I., Schleicher, H., 2003. Experimental hydrothermal alteration of partially metamict zircon. American Mineralogist, 88, 1496-1513.

Goncalves, P., Oliot, E., Marquer, D., Connolly, J.A.D., 2012. Role of chemical processes on shear zone formation: an example from the Grimsel metagranodiorite (Aar massif, Central Alps). Journal of Metamorphic Geology 30, 703-722.

Graham, J.R., 1982. Transition from basin-plain to shelf deposits in the Carboniferous flysch of Southern Morocco. Sediment. Geol. 33, 173-193.

Gueydan, F., Leroy, Y.M., Jolivet, L., Agard, P., 2003. Analysis of continental midcrustal strain localization induced by microfracturing and reaction-softening. Journal of Geophysical Research: Solid Earth 108.

Haas, J.R., Shock, E.L., Sassani, D.C., 1995. Rare earth elements in hydrothermal systems: Estimates of standard partial molal thermodynamic properties of aqueous complexes of the rare earth elements at high pressures and temperatures. Geochimica et Cosmochimica Acta 59, 4329-4350.

Harlov, D.E., Wirth, R., Förster, H.-J., 2005. An experimental study of dissolution-reprecipitation in fluorapatite: fluid infiltration and the formation of monazite. Contributions to Mineralogy and Petrology $150,268-286$

Healy, B., Collins, W.J., Richards, S.W., 2004. A hybrid origin for Lachlan S-type granites: the Murrumbidgee Batholith example. Lithos 78, 197-216.

Hippertt, J., 1998. Breakdown of feldspar, volume gain and lateral mass transfer during mylonitization of granitoid in a low metamorphic grade shear zone. Journal of Structural Geology 20, 175-193.

Huvelin, P., 1977. Etude géologique et gîtologique du massif hercynien des Jebilet (Maroc occidental). Notes et Mem. Serv. Geol. Maroc 232 bis, 307.

Huvelin, P., Ortelli, L., Permingeat, F., Picot, P., 1980. Présence de filons stannifères dans le granite hercynein de Bramram-Tabouchent (Jebilet centrales). Notes et Mémoires Service Géologique Maroc 41, 231-236.

Irber, W., 1999. The lanthanide tetrad effect and its correlation with $\mathrm{K} / \mathrm{Rb}, \mathrm{Eu} / \mathrm{Eu} *, \mathrm{Sr} / \mathrm{Eu}, \mathrm{Y} / \mathrm{Ho}$, and $\mathrm{Zr} / \mathrm{Hf}$ of evolving peraluminous granite suites. Geochimica et Cosmochimica Acta 63, 489-508.

Izart, A., Beauchamp, J., Vachard, D., Tourani, A.-I., Essamani, M., 1997. Stratigraphie séquentielle du Carbonifère inférieur du Haut Atlas central et des Jebilet (Maroc): Un exemple de bassins à turbidites contrôlées par la tectonique. . J. Afr. Earth Sci. 1 24, 445-454.

Jefferies, S.P., Holdsworth, R.E., Wibberley, C.A.J., Shimamoto, T., Spiers, C.J., Niemeijer, A.R., Lloyd, G.E., 2006. The nature and importance of phyllonite development in crustal-scale fault cores: an example from the Median Tectonic Line, Japan. Journal of Structural Geology 28, 220-235.

Jourdan, F., Renne, P.R., 2007. Age calibration of the Fish Canyon sanidine 40Ar/39Ar dating standard using primary K-Ar standards. . Geochimica Cosmochimica Acta 71, 387-402.

Koppers, A.A.P., 2002. ArArCALC software for 40Ar/39Ar age calculations. Computers and Geoscience 28, 605-619.

Lagarde, J.L., 1989. Granites tardi carbonifères et déformation crustale. L'exemple de la Meseta marocaine. Mém. Docs. CAESS, Rennes 26, 353. 
Lagarde, J.L., Aït Omar, S., Roddaz, B., 1990. Structural characteristics of syntectonic plutons with special reference to late carboniferous plutons from Morocco. J. Struct. Geol. 12, 805-821.

Lagarde, J.L., Choukroune, P., 1982. Cisaillement ductile et granitoïdes syntectoniques : l'exemple du massif hercynien des Jebilet (Maroc). Bull. Soc. Géol. France t. XXIV, n² 2, 299-307.

Le Corre, C., Saquaque, A., 1987. Comportement d'un système pluton-encaissant dans un champ de déformation régional : le granite de Bramram (Jebilet, Maroc hercynien). Bull. Soc. Geol. France III, 4, 665-673.

Lee, J.-Y., Marti, K., Severinghaus, J.P., Kawamura, K., H-S., Y., Lee, J.B., Kim, J.S., 2006. A redetermination of the isotopic abundances of atmospheric Ar. Geochimica et Cosmochimica Acta 70, $4507-4512$.

Leroy, J.L., Turpin, L., 1988. REE, Th and U behaviour during hydrothermal and supergene processes in a granitic environment. Chemical Geology 68, 239-251.

Linnen, R.L., Keppler, H., 1997. Columbite solubility in granitic melts: consequences for the enrichment and fractionation of $\mathrm{Nb}$ and $\mathrm{Ta}$ in the Earth's crust. Contributions to Mineralogy and Petrology 128, 213227.

Linnen, R.L., Keppler, H., 2002. Melt composition control of $\mathrm{Zr} / \mathrm{Hf}$ fractionation in magmatic processes. Geochimica et Cosmochimica Acta 66, 3293-3301.

Loges, A., Wagner, T., Barth, M., Bau, M., Göb, S., Markl, G., 2012. Negative Ce anomalies in Mn oxides: The role of $\mathrm{Ce}^{4+}$ mobility during water-mineral interaction. Geochimica et Cosmochimica Acta $86,296-317$

Marcoux, E., Belkabir, A., Gibson, H.L., Lentz, D., Ruffet, G., 2008. Draa Sfar, Morocco: A Visean (331 Ma) pyrrhotite-rich, polymetallic volcanogenic massive sulphide deposit in a Hercynian sedimentdominant terrane. Ore Geology Reviews 33, 307-328.

Massonne, H. J., Schreyer, W., 1987. Phengite geobarometry based on the limiting assemblage with Kfeldspar, phlogopite, and quartz. Contributions to Mineralogy and Petrology, 96, 212-224.

McDonough, W.F., Sun, S.S., 1995. The Composition of the Earth; Chemical Geology 120, 223-253.

Michard, A., Soulaimani, A., Hoepffner, C., Ouanaimi, H., Baidder, L., Rjimati, E.C., Saddiqi, O., 2010. The South-Western Branch of the Variscan Belt: Evidence from Morocco. . Tectonophysics 492, 1-24.

Migdisov, A.A., Williams-Jones, A.E., 2014. Hydrothermal transport and deposition of the rare earth elements by fluorine-bearing aqueous liquids. Mineralium Deposita 49, 987-997.

Mohammadi, N., McFarlane, C.R.M., Lentz, D.R., Thorne, K.G., 2020. Timing of magmatic crystallization and $\mathrm{Sn}-\mathrm{W}-\mathrm{Mo}$ greisen vein formation within the Mount Douglas Granite, New Brunswick, Canada. Canadian Journal of Earth Sciences 57, 814-839.

Monecke, T., Kempe, U., Monecke, J., Sala, M., and Wolf, D., 2002, Tetrad effect in rare earth element distribution patterns: A method of quantification with application to rock and mineral samples from granite-related rare metal deposits: Geochimica et Cosmochimica Acta, v. 66, p. 1185- 1196

Monecke, T., Dulski, P., Kempe, U., 2007. Origin of convex tetrads in rare earth element patterns of hydrothermally altered siliceous igneous rocks from the Zinnwald Sn-W deposit, Germany. Geochimica et Cosmochimica Acta 71, 335-353.

Mrini, Z., Rafi, A., Duthou, J.-L., Vidal, P., 1992. Chronologie Rb-Sr des granitoïdes hercyniens du Maroc : conséquences. Bull. Soc. Géol. France 163, 281-291. 
N'Diaye, I., Essaifi, A., Dubois, M., Lacroix, B., Goodenough, K.M., Maacha, L., 2016. Fluid flow and polymetallic sulphide mineralization in the Kettara shear zone (Jebilet Massif, Variscan Belt, Morocco). J. Afr. Earth Sci. 119, 17-37.

Piqué, A., Jeannette, D., Michard, A., 1980. The western meseta shear zone, a major and permanent feature of the Hercynian belt in Morocco. J. Struct. Geol. 2, 397-410.

Piqué, A., Michard, A., 1989. Moroccan hercynides : a synopsis. The paleozoic sedimentary and tectonic evolution at the northern margin of west Africa. Am. J. Sci 289, 286-330.

Pirajno, F., 2013. Effects of metasomatism on mineral systems and their host rocks: alkali metasomatism, skarns, greisens, tourmalinites, rodingites, black-wall alteration and listvenites, Metasomatism and the Chemical Transformation of Rock. Springer, pp. 203-251.

Playford, G., González, F., Moreno, C., Al Ansari, A., 2008. Palynostratigraphy of the Sarhlef Series (Mississippian), Jebilet Massif, Morocco. Micropaleontology 54, 89-124.

Poitrasson, F., Chenery, S., Shepherd, T.J., 2000. Electron microprobe and LA-ICP-MS study of monazite hydrothermal alteration: Implications for $\mathrm{U}-\mathrm{Th}-\mathrm{Pb}$ geochronology and nuclear ceramics. Geochimica et Cosmochimica Acta 64, 3283-3297.

Rasmussen, B., Muhling, J.R., 2007. Monazite begets monazite: evidence for dissolution of detrital monazite and reprecipitation of syntectonic monazite during low-grade regional metamorphism. Contributions to Mineralogy and Petrology 154, 675-689.

Rasmussen, B., Muhling, J.R., 2009. Reactions destroying detrital monazite in greenschist-facies sandstones from the Witwatersrand basin, South Africa. Chemical Geology 264, 311-327.

Roddaz, M., Brusset, S., Soula, J.C., Beziat, D., Ben Abbou, M., Debat, P., Driouch, Y., Christophoul, F., Ntarmouchant, A., Deramond, J., 2002. Foreland basin magmatism in the Western Moroccan Meseta and geodynamic inferences - art. no. 1043. Tectonics 21, NIL_137-NIL_159.

Rolland, Y., Cox, S., Boullier, A.-M., Pennacchioni, G., Mancktelow, N., 2003. Rare earth and trace element mobility in mid-crustal shear zones: insights from the Mont Blanc Massif (Western Alps). Earth and Planetary Science Letters 214, 203-219.

Rossi, M., Rolland, Y., Vidal, O., Cox, S. F., 2005. Geochemical variations and element transfer during shear-zone development and related episyenites at middle crust depths: insights from the Mont Blanc granite (French-Italian Alps). Geological Society, London, Special Publications, 245(1), 373-396.

Salvi, S., Williams-Jones, A.E., 1996. The role of hydrothermal processes in concentrating high-field strength elements in the Strange Lake peralkaline complex, northeastern Canada. Geochimica et Cosmochimica Acta 60, 1917-1932.

Saquaque, A., 1985. Déformation et mise en place d'un pluton syncinématique: l'exemple du granite hercynien de bramram-Tabouchennt-Bamega (Jebilet centrales, Maroc). Univ. Marrakech.

Selverstone, J., Morteani, G., Staude, J.M., 1991. Fluid channeling during ductile shearing: transformation of granodiorite into aluminous schist in the Tauern Window, eastern Alps. J. Metamorphic Geol. 9, 419-431.

Seward T.M., Wiliams-Jones, A.E. and Migdisov A.A., 2014. The chemistry of metal transport and deposition by ore-forming hydrothermal fluids. Treatise on geochemistry (Second Edition). 13, 29-57

Simancas, J.F., Azor, A., Martínez Poyatos, D.J., Tahiri, A., El Hadi, H., González-Lodeiro, F., PérezEstaún, A., Carbonell, R., 2009. Tectonic relationships of Southwest Iberia with the allochthons of Northwest Iberia and the Moroccan Variscides. C. R. Geoscience 341, 103-113.

Sinha, A.K., D.A., H., Rimstidt, J.D., 1986. Fluid interaction and element mobility in the development of ultramylonites. 
Smith, M.P., Henderson, P., Campbell, L.S., 2000. Fractionation of the REE during hydrothermal processes: Constraints from the Bayan Obo Fe-REE-Nb deposit, Inner Mongolia, China. Geochimica et Cosmochimica Acta 64, 3141-3160.

Steiger, R.H., Jäger, E., 1977. Subcommission on geochronology: Convention on the use of decay constants in geo- and cosmochronology. Earth and Planetary Science Letters 36, 359-362.

Streit, J.E., Cox, S.F., 1998. Fluid infiltration and volume change during mid-crustal mylonitization of Proterozoic granite, King Island, Tasmania. J. metamorphic Geol. 16, 197-212.

Stünitz, H., Fitz Gerald, J.D., 1993. Deformation of granitoids at low metamorphic grade. II. Granular flow in albite-rich mylonites. Tectonophysics 221, 299-324.

Tisserant, D., 1977. Les isotopes du strontium et l'histoire hercynienne du Maroc, Étude de quelques massifs atlasiques et mésétiens.

Tursi, F., Festa, V., Fornelli, A., Micheletti, F., Spiess, R., 2018. Syn-shearing mobility of major elements in ductile shear zones: state of the art for felsic deformed protoliths. Periodico di Mineralogia 87, 289308.

Vasyukova, O., Williams-Jones, A., 2016. The evolution of immiscible silicate and fluoride melts: Implications for REE ore-genesis. Geochimica et Cosmochimica Acta 172, 205-224.

Walter, A.-V., Flicoteaux, R., Parron, C., Loubetb, M., Nahona, D., 1995. Rare-earth elements and isotopes ( $\mathrm{Sr}, \mathrm{Nd}, 0, \mathrm{C})$ in minerals from the Juquiti carbonatite (Brazil) : tracers of a multistage evolution. Chemical Geology 120 27-44.

Ward, C.D., Mcarthur, J.M., Walsh, N.J., 1992. Rare Earth Element Behaviour During Evolution and Alteration of the Dartmoor Granite, SW England. Journal tf Petrology 33, 783-815.

Wendlandt, R.F., Harrison, W.J., 1979. Rare Earth Partitioning Between Immiscible Carbonateand Silicate Liquids and $\mathrm{CO}$ z Vapor: Results and Implications for the Formation of Light Rare EarthEnriched Rocks. Contrib. Mineral. Petrol. 69, 409-419.

Wibberley, C.A.J., McCaig, A.M., 2000. Quantifying orthoclase and albite muscovitisation sequences in fault zones. Chemical Geology 165, 181-196.

Williams-Jones, A.E., Migdisov, A.A., Samson, I.M., 2012. Hydrothermal Mobilisation of the Rare Earth Elements - a Tale of "Ceria" and "Yttria". Elements 8, 355-360.

Wintsch, R.P., Christoffersen, R., Kronenberg, A.K., 1995. Fluid-rock reaction weakening of fault zones. Journal of Geophysical Research: Solid Earth 100, 13021-13032.

Wood, S.A., 1990. The aqueous geochemistry of the rare-earth elements and yttrium 2. Theoretical predictions of speciation in hydrothermal solutions to $350^{\circ} \mathrm{C}$ at saturation water vapor pressure. Chemical Geology 88, 99-125.

\section{Figure captions}

Figure 1. Geological sketch map of the Jebilet massif (modified after Huvelin, 1977). Location of figure 2 is indicated. Inset: the Jebilet massif in the frame of the Variscan Belt of Morocco.

Figure 2. A) Geologic sketch map of the Central Jebilet pluton and the western margin of the Oulad Ouaslam pluton showing the distribution of the major rock types and the map-scale schistosity 
trajectories within the intrusions and the country rocks. Modified after Huvelin (1977), Saquaque (1985), Chemesseddoha (1986), and Lagarde (1989). Note the regional-scale Marrakech Shear Zone (MSZ) and the Tabouchent Shear Zone (TSZ). B) Vertical E-W cross section through the Tabouchent and Bramram intrusions.

Figure 3. Map-scale schistosity trajectories $\left(\mathrm{S}_{1}\right)$ and deformation kinematics within the TabouchentBamega-Bramram pluton and its host rocks (modified after Saquaque, 1985). The Tabouchent Shear Zone is indicated in grey. Encircled numbers correspond to location of the shear zone profiles and samples in Table 2. 1 (TB3, TB4, TB5); 2 (TB6, TB7), 3 (TB10, TB11, TB12), 4 (TB18, 19); 5 (TB28, TB29); 6 (TB15, TB16, ТВ17); 7 (ТВ22, ТВ23, ТВ24); 8 (TB13, ТВ14); 9 (TB8, TB9); 10 (TB30 leucogranite); 11 (TB20; TB21); 12 (TB25, TB26, TB27); 13 (TB2); 14 (TB33 greisen), 15 (TB32 leucogranite), and 16 (the dated sample JB14-02).

Figure 4. Field shots and photographs illustrating deformation/alteration in the Tabouchent intrusion. A) Field view of a shear zone crosscutting the granodiorite, B) leucogranite veins within the granodiorite, C) quartz-tourmaline nest within leucogranite, D) meter-scale shear zone within granodiorite, E-J) an example of hand samples collected along a shear zone profile with E-F) undeformed granodiorite, G-H) mylonitized granodiorite from the shear zone margin, I-J) ultramylonitized granodiorite from the shear zone core. S/C (shear bands), K-feldspar (Kfs), Plagioclase (Pl), Quartz (Qz), Biotite (Bt).

Figure 5. Thin section views of the Tabouchent undeformed granodiorite and crosscutting shear zones, A-B) undeformed granodiorite showing perthetic K-feldspar (Kfs), Plagioclase (Pl), quartz (Qz), Biotite (Bt) with inclusions of zircon ( $\mathrm{Zrn})$, monazite (Mnz), apatite (Ap), and ilmenite (Ilm) and showing transformation into muscovite (Ms), C-D) mylonitized granodiorite showing feldspar relics and deformed quartz grains within a chlorite (Chl) and muscovite-rich matrix (Ser), E-F) ultramylonitized granodiorite showing recrystallized quartz grains within quartz and muscovite + /- chlorite matrix.

Figure 6. SEM images showing the distribution of REE-bearing minerals in the undeformed granodiorite. Min abbreviations : Ap - apatite, $\mathrm{Bt}$ - biotite, Ilm - ilmenite, Mnz - monazite, Zrc - zircon, Xnt - xenotime

Figure 7. SEM images and a phase map showing the distribution of REE-bearing phases in the sheared and chemically altered granodiorites, A - stringers of monazite in the cleavage of chlorite ; B - Ce oxide in shear-plane parallel fissures, here in association with muscovite; $\mathrm{C}$ - Intact zircon and fractured apatite within chlorite and Ti oxide-rich matrix; D-E - fluorocarbonates in association with $\mathrm{Ti}$ oxide and $\mathrm{Fe} \pm \mathrm{Cu}$ oxide; F - complex intergrowth of finely-crystalline apatite, monazite, Th-rich phosphate and xenotime in association with muscovite and chlorite $; \mathrm{G}$ - mineralogical phase map showing the distribution of syntectonic REE-bearing phases (the phase map is underlain by BSE image, hence the localised variation in the shade of a given phase) and $\mathrm{H}$ - inset with fine details of the intimate intergrowth of finely crystalline syntectonic Th-rich phosphate and xenotime. Note the euhedral, rhombic crystals of the Thrich phosphate present locally within this assemblage. Min abbreviations: Ap - apatite, Bt - biotite, Chl - chlorite, Ilm - ilmenite, Mnz - monazite, Ms - muscovite, Qz - quartz, Zrc - zircon, Xnt - xenotime

Figure 8. ${ }^{40} \mathrm{Ar} /{ }^{39} \mathrm{Ar}$ age spectra as a function of released ${ }^{39} \mathrm{Ar}$ on muscovite single grain from the mylonitic granite JB14-02. The error boxes for each step age are at the $2 \sigma$ level. Ages were calculated using the ArArCalc program of Koppers (2002).

Figure 9. Projection of the shear zones and their undeformed counterparts in the Shand (1943) diagram $\left(\mathrm{A} / \mathrm{CNK}=\mathrm{Al}_{2} \mathrm{O}_{3} /\left(\mathrm{CaO}+\mathrm{Na}_{2} \mathrm{O}+\mathrm{K}_{2} \mathrm{O}\right) ; \mathrm{A} / \mathrm{NK}=\left(\mathrm{Al}_{2} \mathrm{O}_{3} / \mathrm{Na}_{2} \mathrm{O}+\mathrm{K}_{2} \mathrm{O}\right)\right.$; molar proportions $)$. The lowest $\mathrm{A} / \mathrm{CNK}$ value (1.27) is displayed by the less altered undeformed rock sample (TB8).

Figure 10. Harker diagrams of selected major and trace elements for the Tabouchent shear zones and their undeformed granodioritic counterparts. Model silica enrichment or depletion trends are shown as arrows in $\mathrm{SiO}_{2}$ vs. $\mathrm{Al}_{2} \mathrm{O}_{3}$ and $\mathrm{TiO}_{2}$ plots, based on a mass balance calculation of silica subtraction (or inversely, addition) from the average undeformed graniodiorite composition. 
Figure 11. Chondrite-normalized REE patterns of selected shear zones and their undeformed counterparts. Normalizing values are from McDonough and Sun (1995).

Figure 12. Isocon plots illustrating two cases of REE mobility. A) REE immobile. The $\mathrm{R}^{2}$ value indicates the linear correlation for REE, which is superposed to the Al-Ti isocon, B Coupled enrichment in LREE and HREE. The blue line represents the Al-Ti isocon and the $\mathrm{R}^{2}$ values indicate the linear correlations for LREE (green line) and HREE (red line). The nature of the volume change $(\Delta \mathrm{V}>0$ or $<0)$ is indicated by the bold arrow.

Figure 13. Isocon plots illustrating REE depletion without any fractionation between LREE and HREE (A), LREE depleted relatively to HREE (B), and LREE less depleted than HREE (C). The blue line represents the $\mathrm{Al}-\mathrm{Ti}$ isocon and the $\mathrm{R}^{2}$ values indicate the linear correlations for LREE (green line) and HREE (red line). The nature of the volume change $(\Delta \mathrm{V}>0$ or $<0)$ is indicated by the bold arrow.

Figure 14. Percentage of REE mass change for a shear zone characterized by local REE redistribution. Mass gains are positive, losses are negative. They are calculated relatively to the least altered undeformed granodiorite (TB8 sample).

Figure 15. Total REE vs. light rare earth elements, $\mathrm{Yb}$ and $\mathrm{Lu}$ in the Tabouchent granodioritic shear zones and their undeformed counterparts.

Figure 16. Mass changes for $Y$ vs. mass changes for $\operatorname{HREE~(a-g)~and~} Y$ mass changes vs. $\operatorname{REE}_{\max }(\mathrm{h})$. $\mathrm{REE}_{\max }$ denotes the maximum change for any REE in the rock. The mass changes are calculated relatively to the least deformed and altered sample (TB8).

Figure 17. Plot of the Tabouchent granodioritic shear zones and their undeformed counterparts in the $\mathrm{Nb} / \mathrm{Ta}$ vs. Zr/Hf diagram (A) and vs. the degree of tetrad effect $\mathrm{TE}_{1-3}(\mathrm{~B})$. Intruding leucogranites and associated greisen are also plotted. Fields in (A) from Ballouard et al. (2016). The degree of tetrad effect $\mathrm{TE}_{1-3}$ has been calculated using the equation of Irber (1999).

Figure 18. Conceptual genetic model for the zonation of the mineralization around the Tabouchent intrusion. Fluids exsolved from a causative leucogranitic intrusion at depth are channelized along the Tabouchent Shear Zone and lead to Sn-W intrusion-hosted mineralization, proximal $\mathrm{Cu}-\mathrm{Au}$ and distal $\mathrm{Pb}-\mathrm{Zn}-\mathrm{Ag}$ mineralizations in the country rocks. 


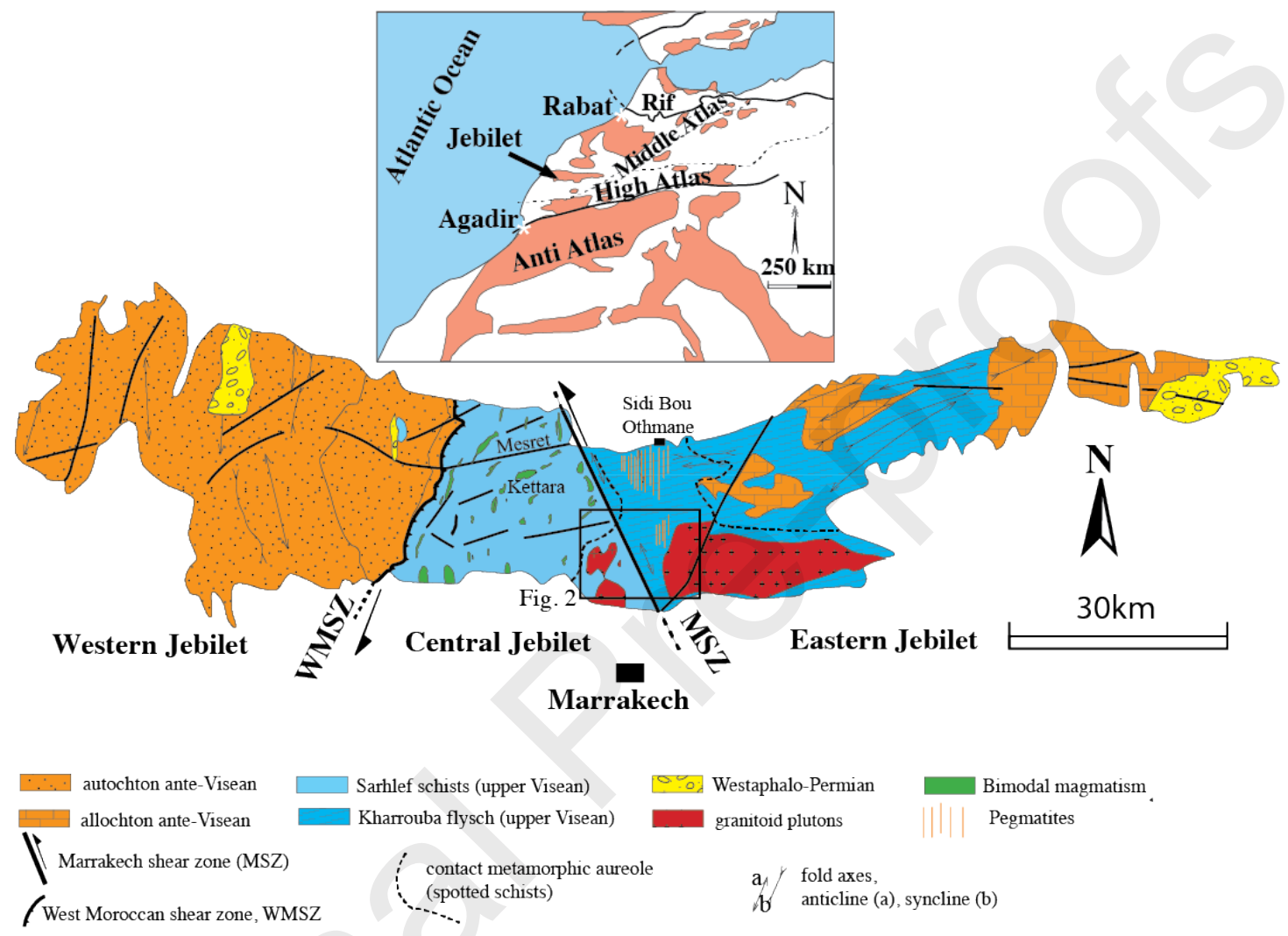

Fig. 1 


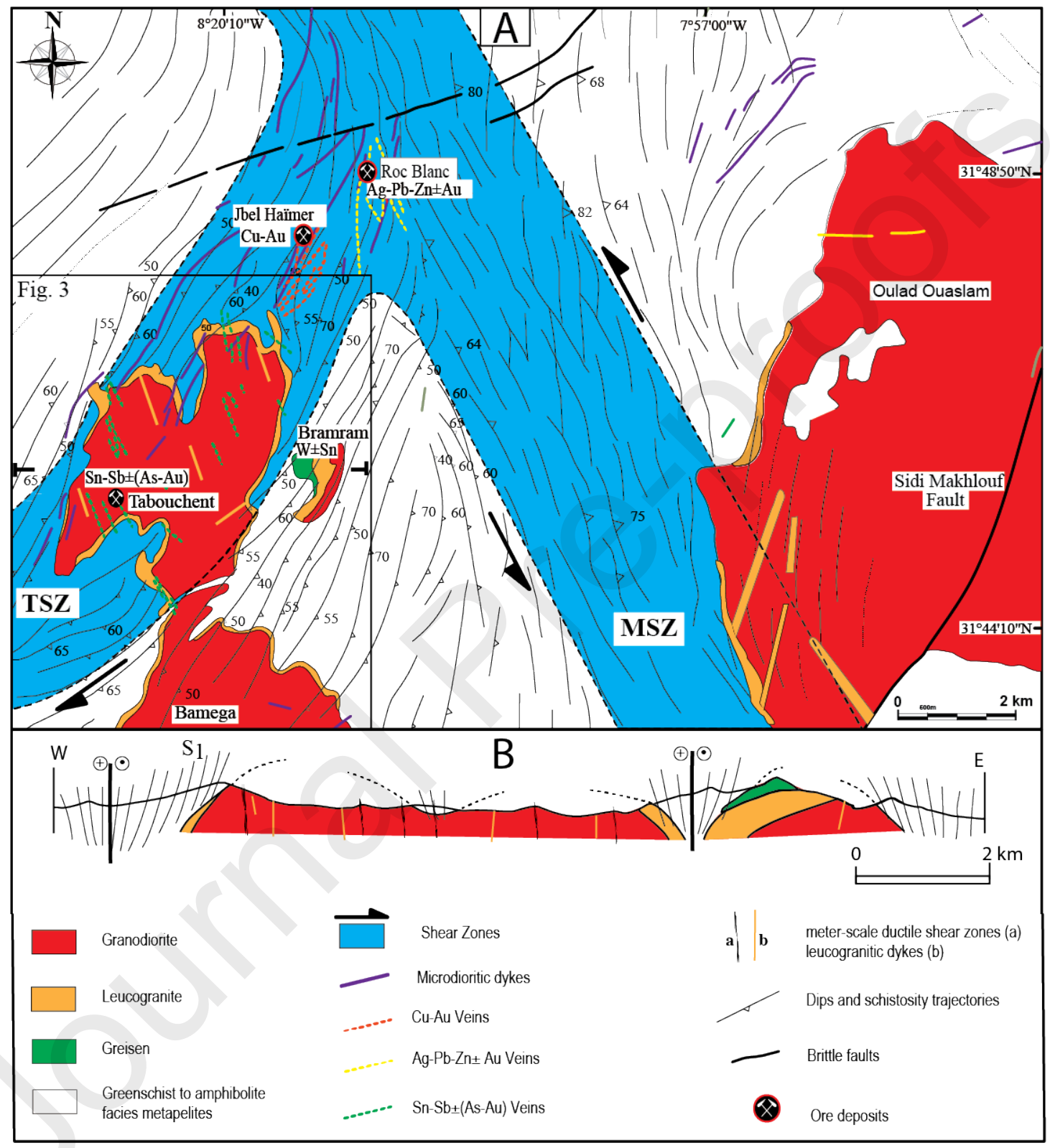

Fig. 2 


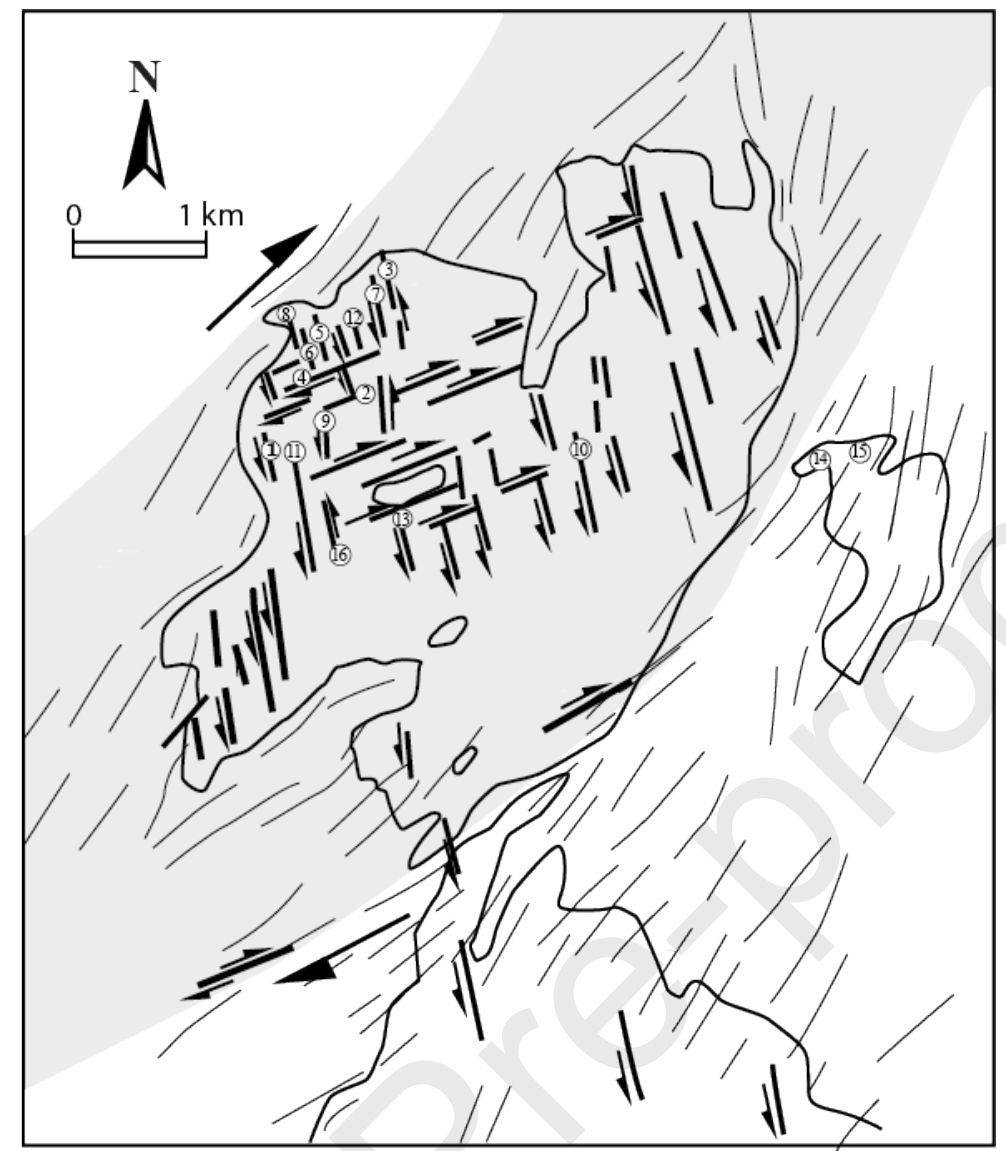

Fig. 3 

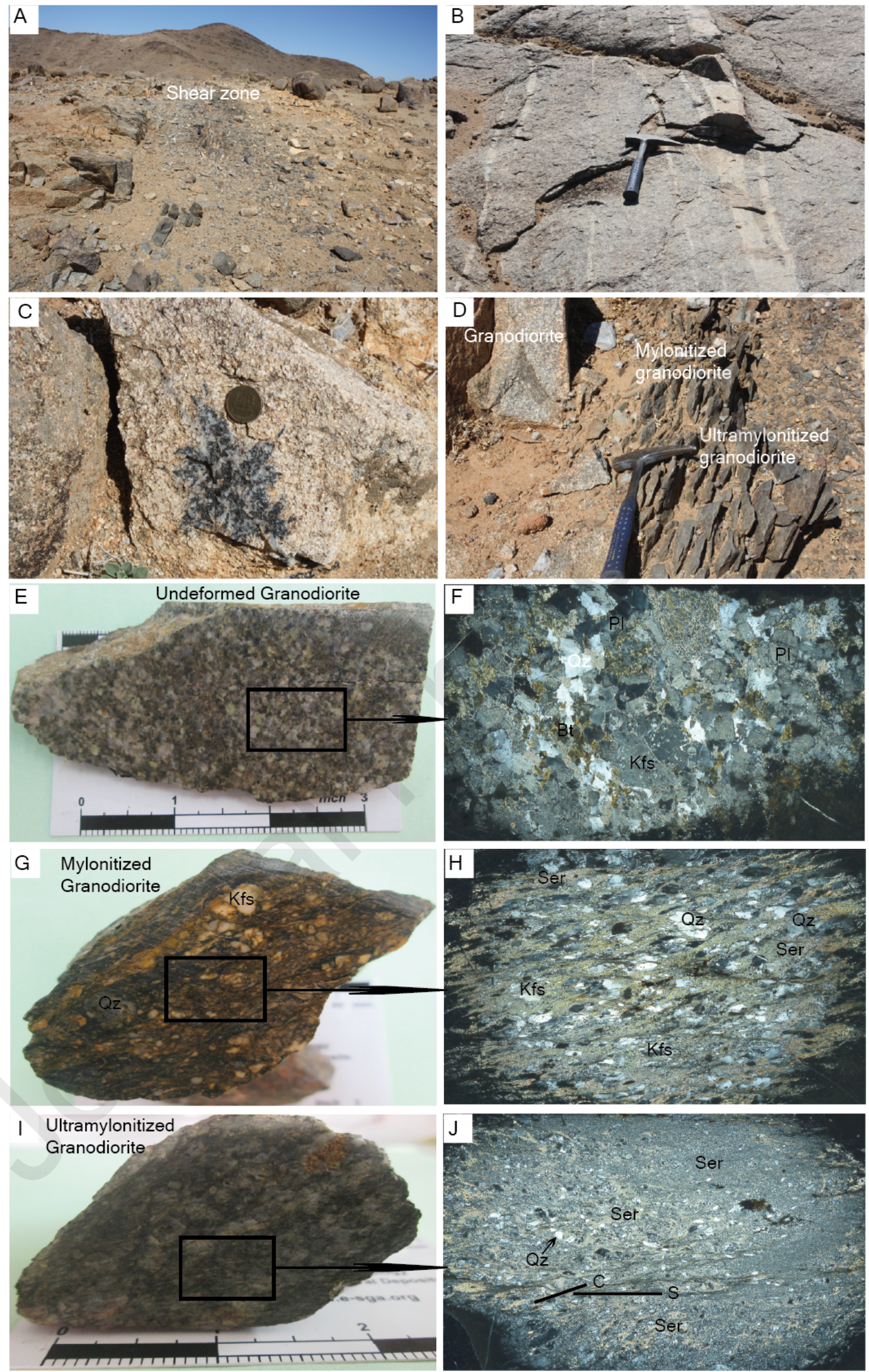

Fig. 4 
Journal Pre-proofs
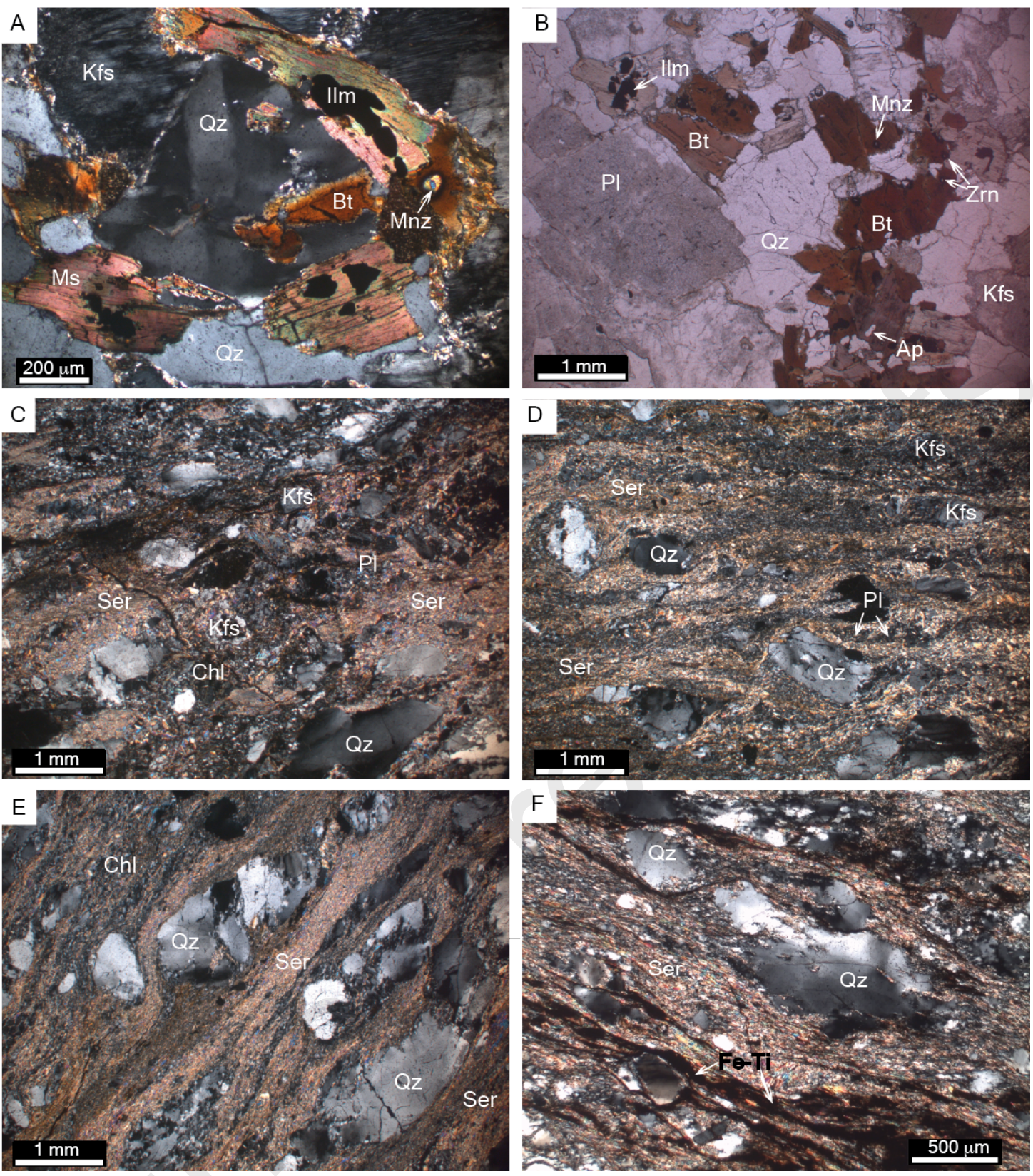

Fig. 5 

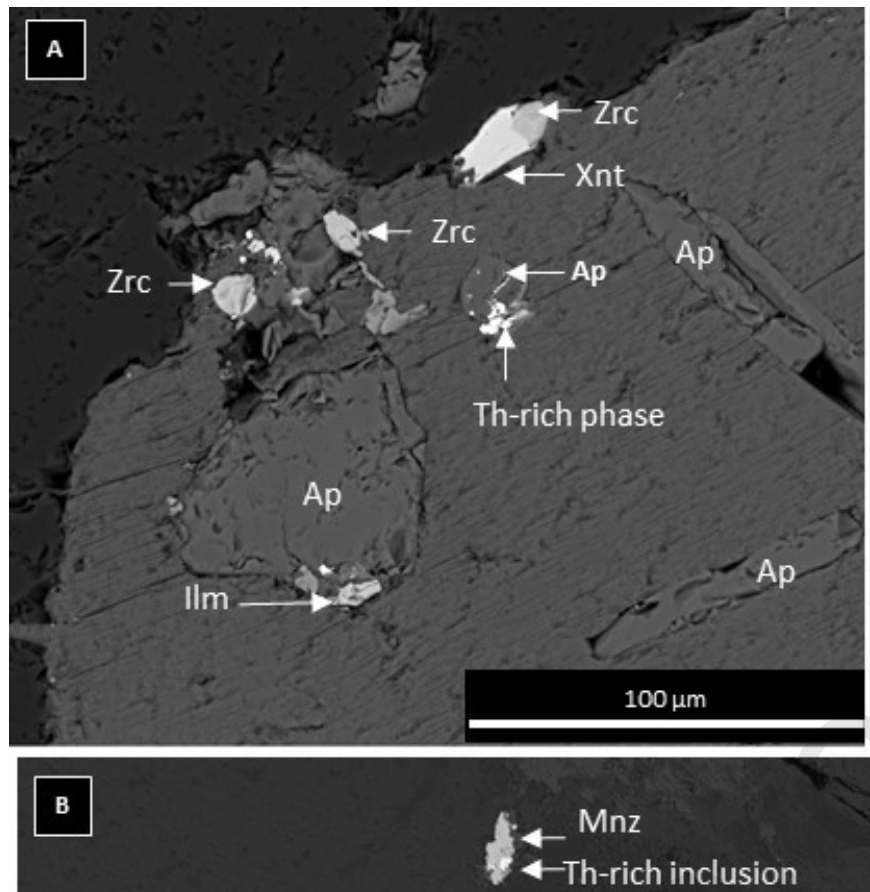

Fig. 6 


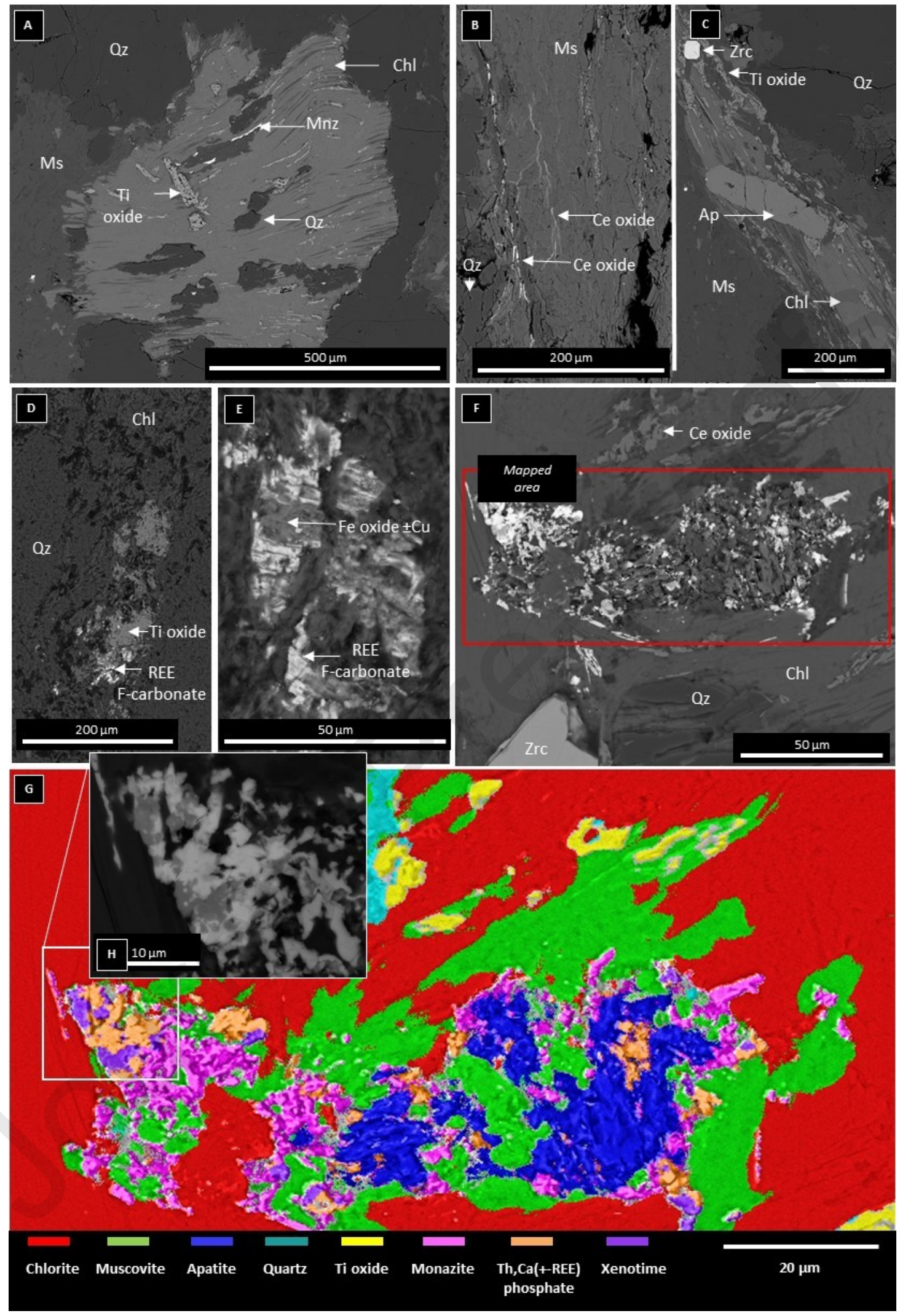

Fig. 7 


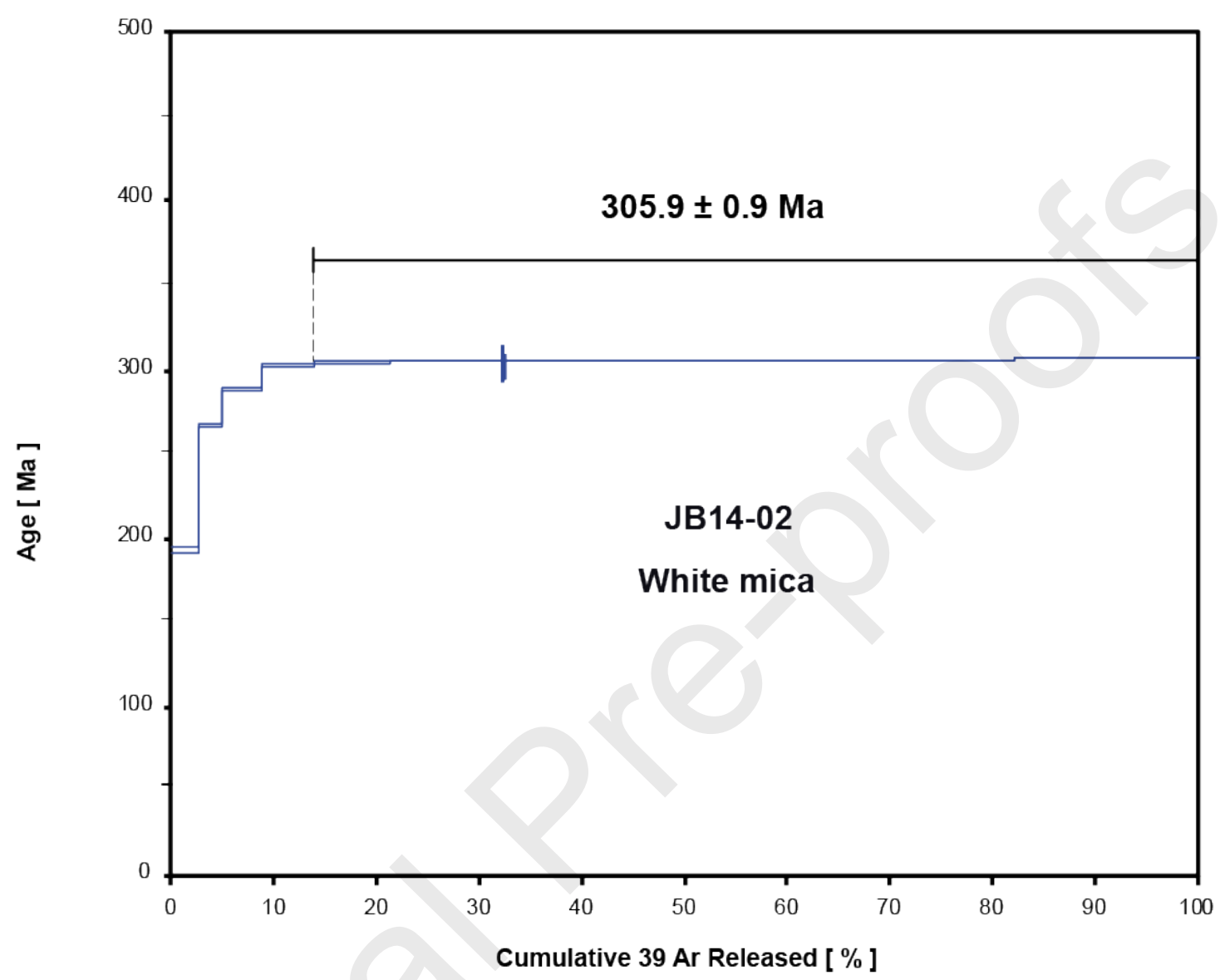

Fig. 8 


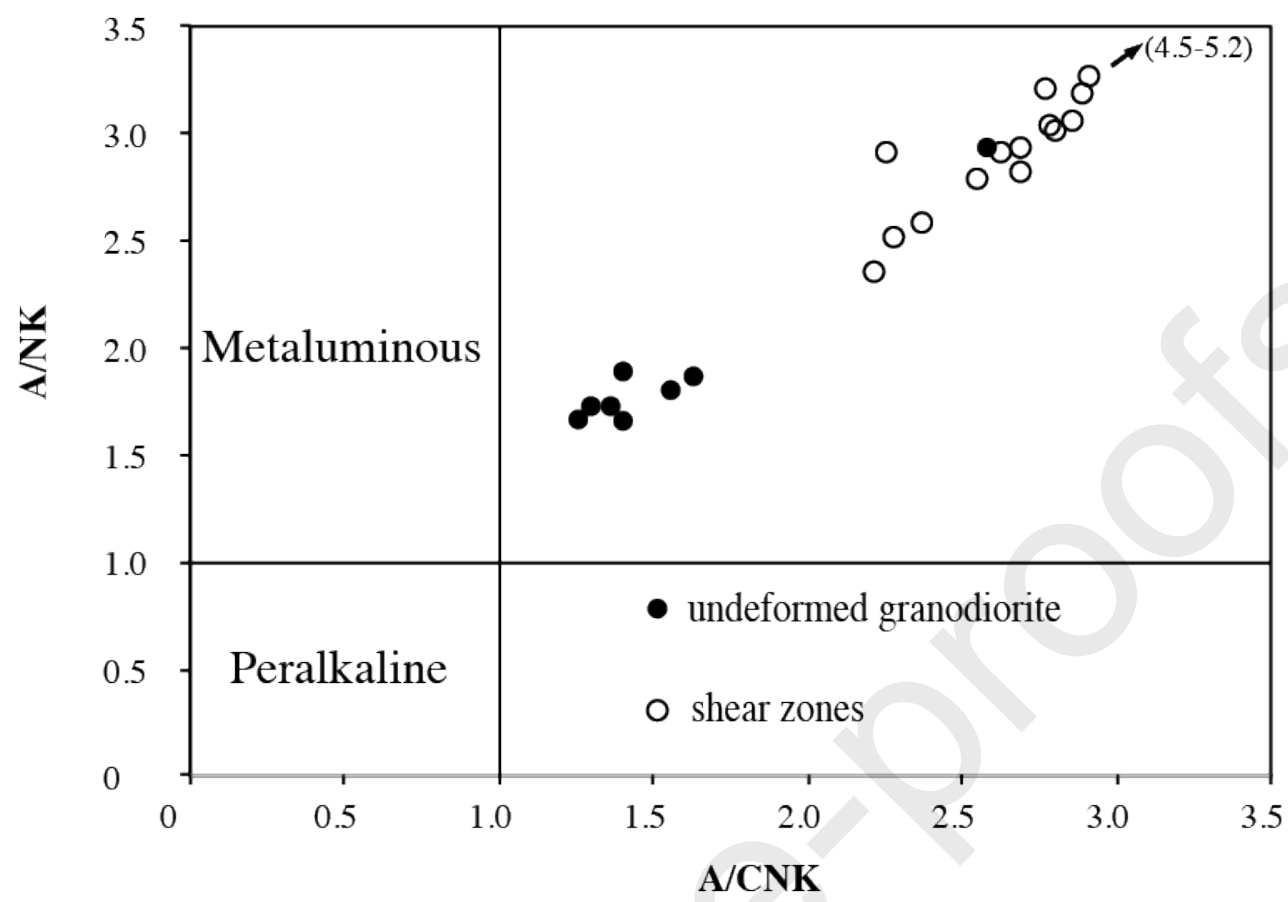

Fig. 9 

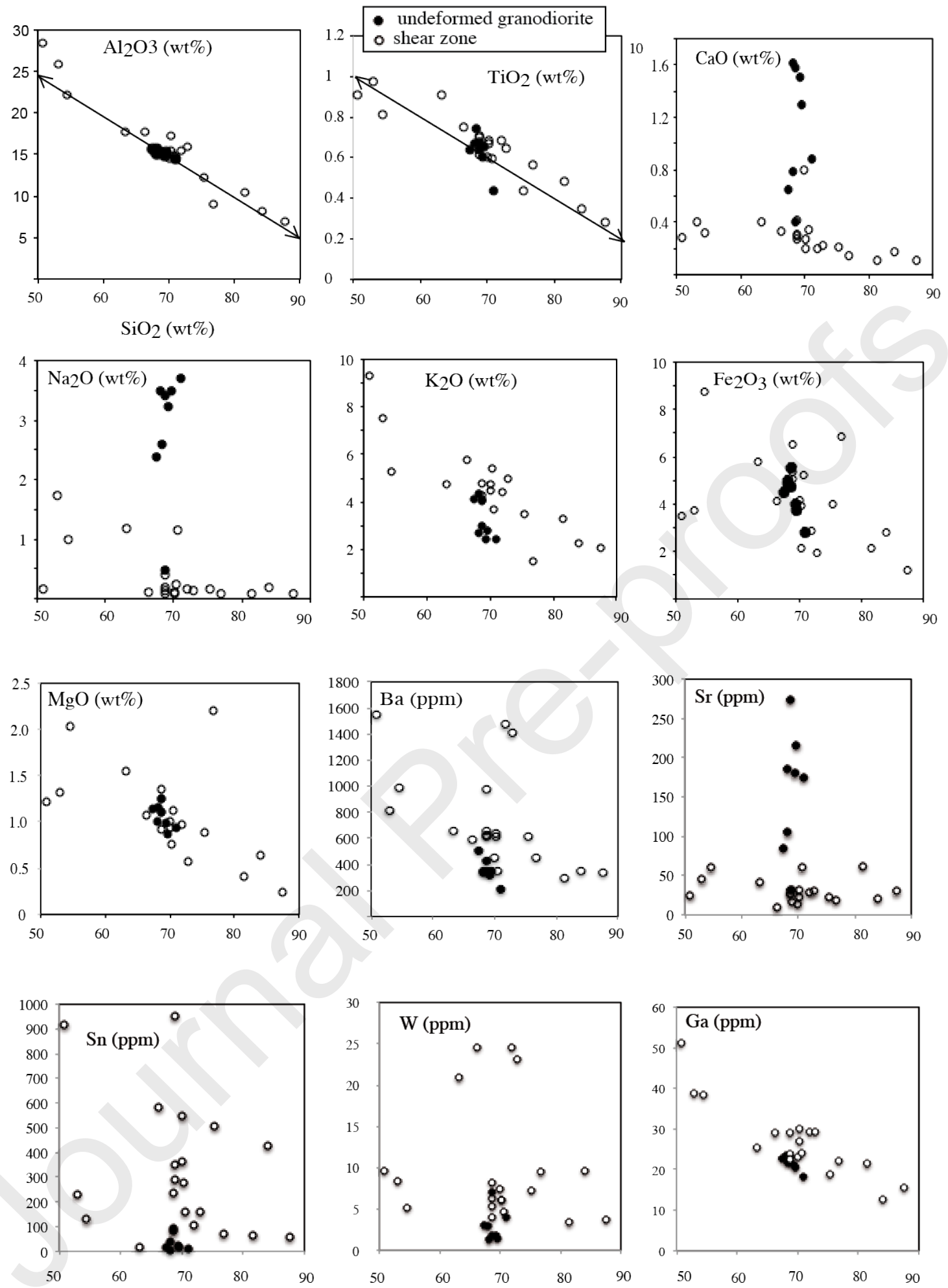

Fig. 10 


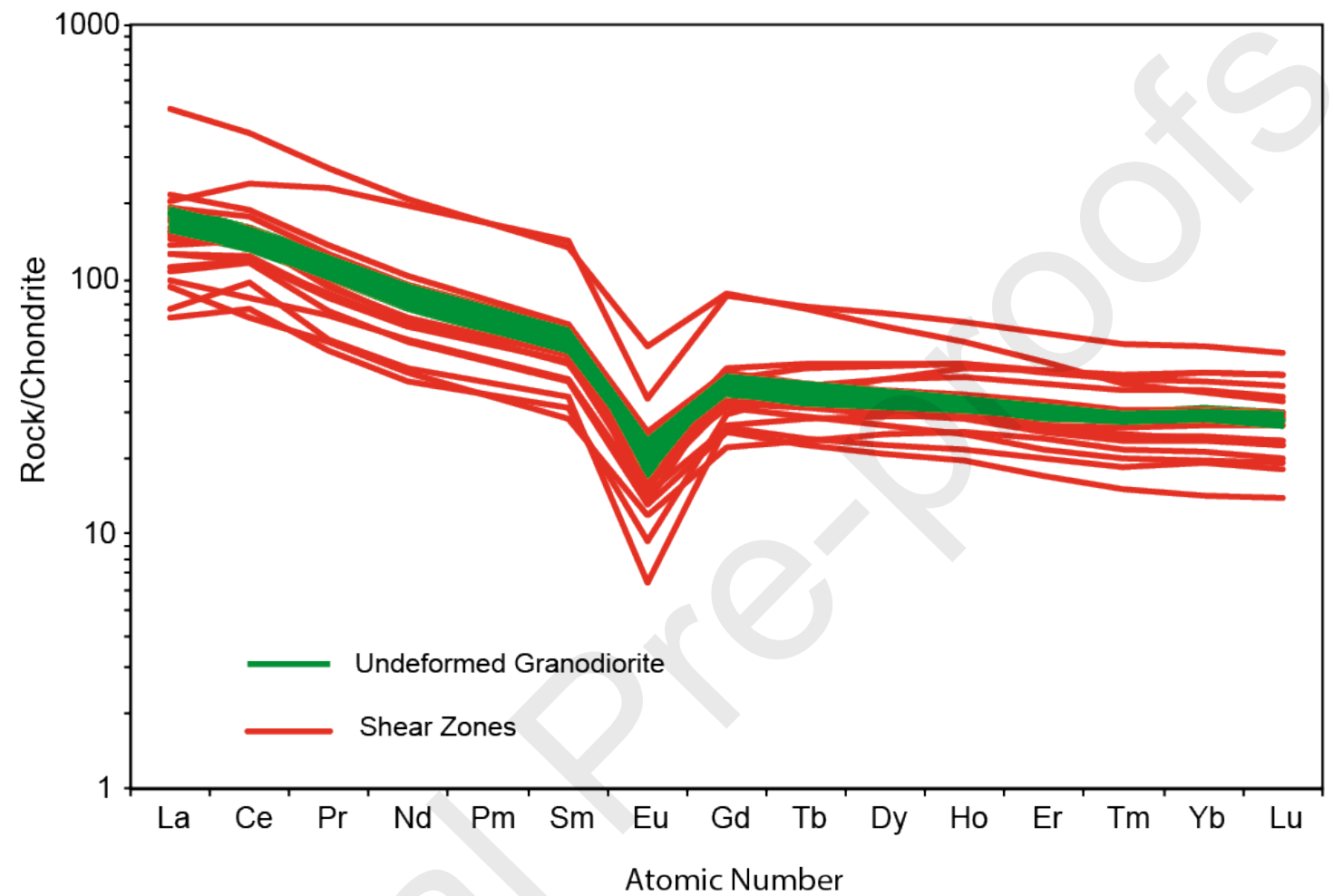

Fig. 11 
(A)

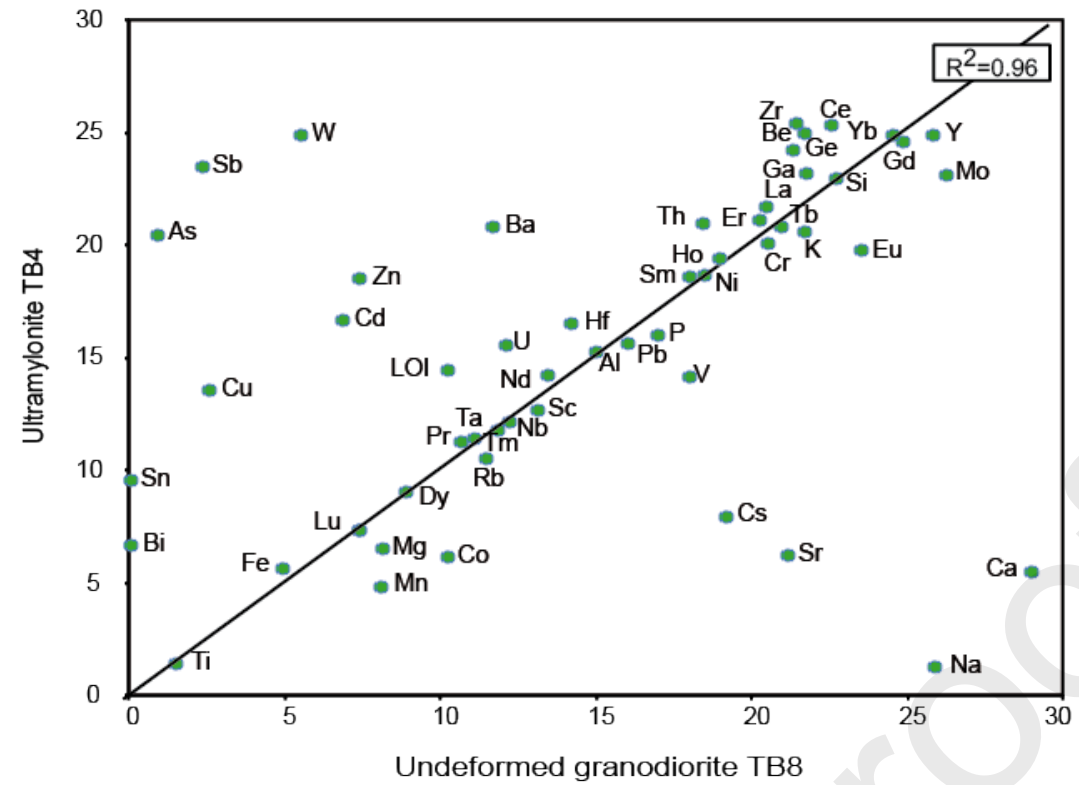

(B)

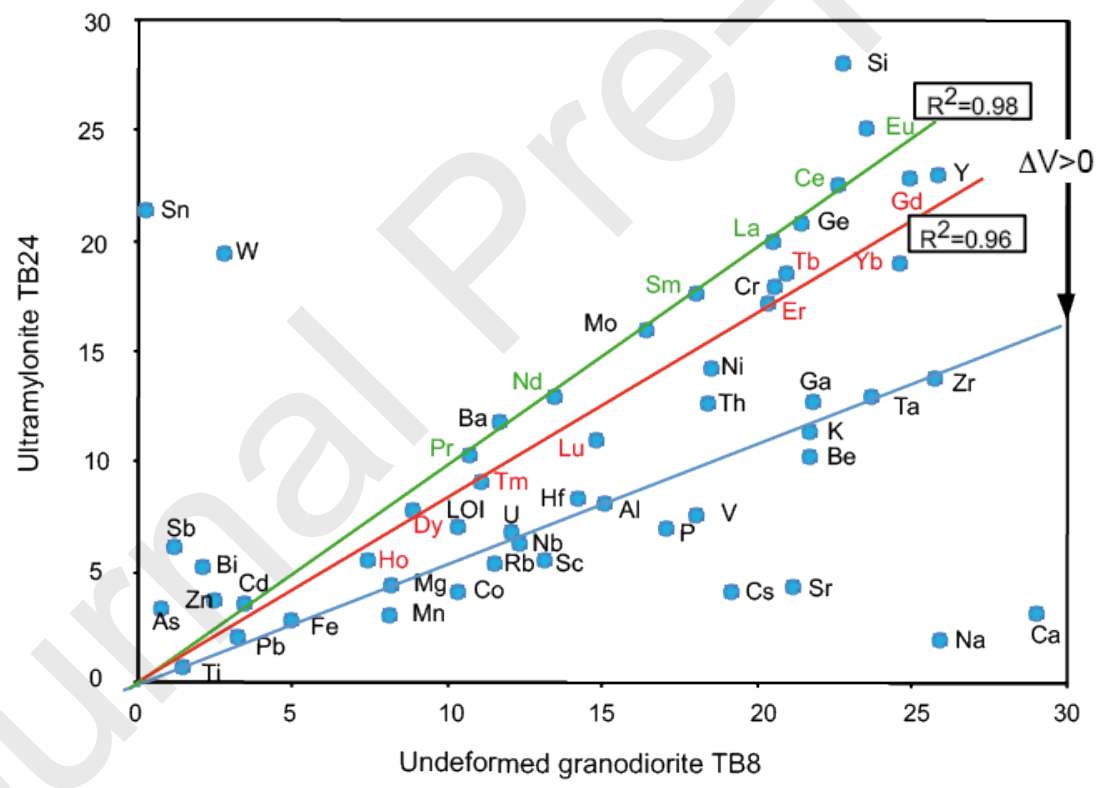

Fig. 12 


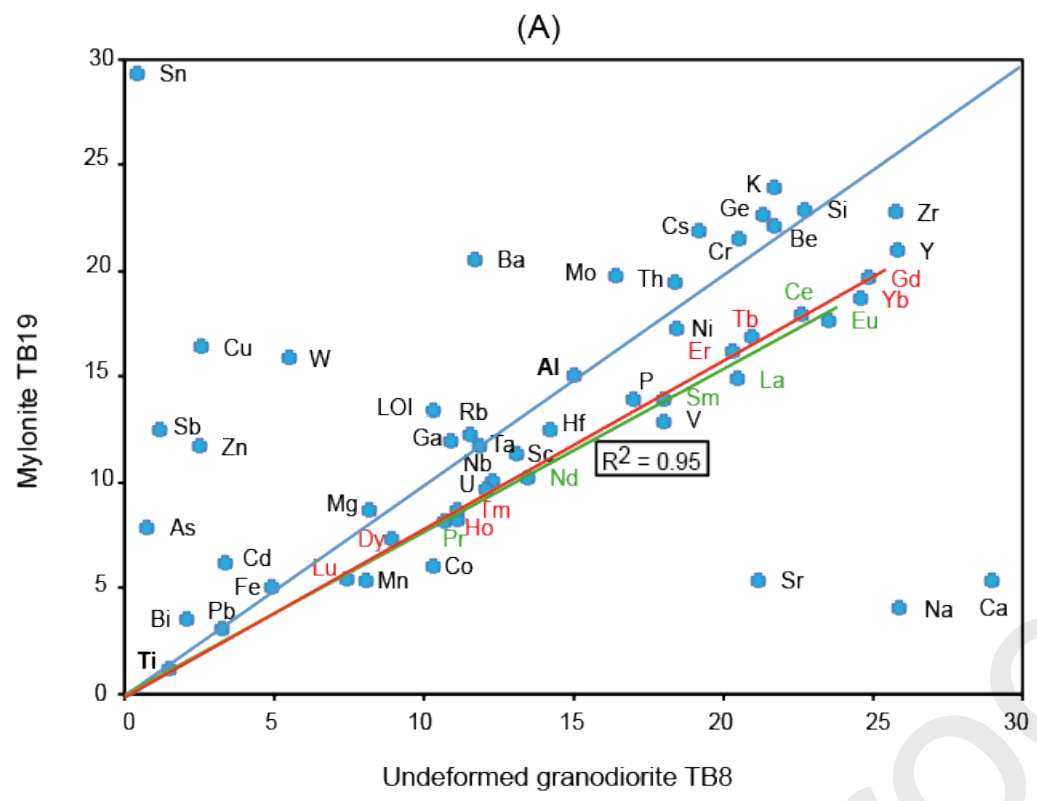

(B)
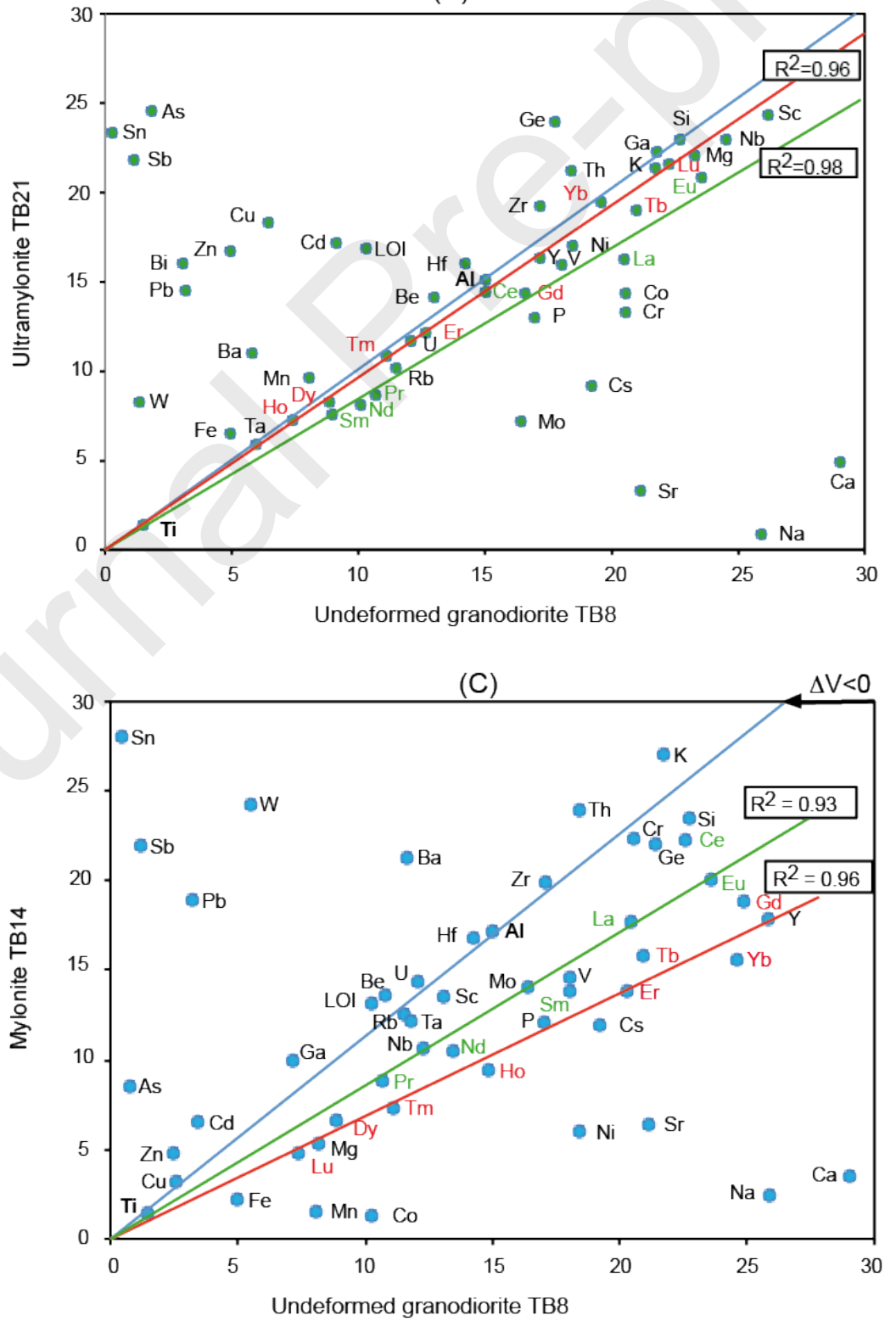
Fig. 13

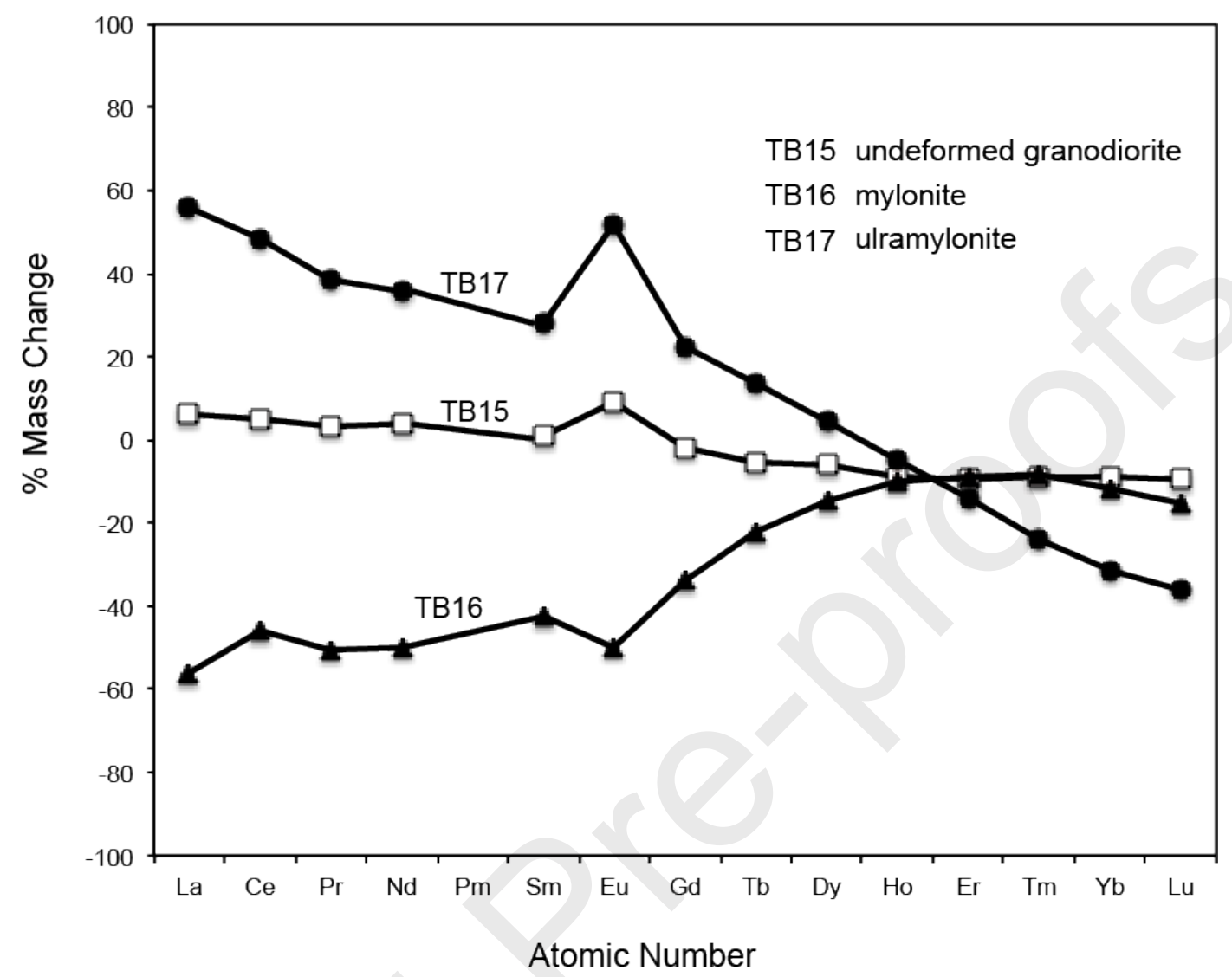

Fig. 14 

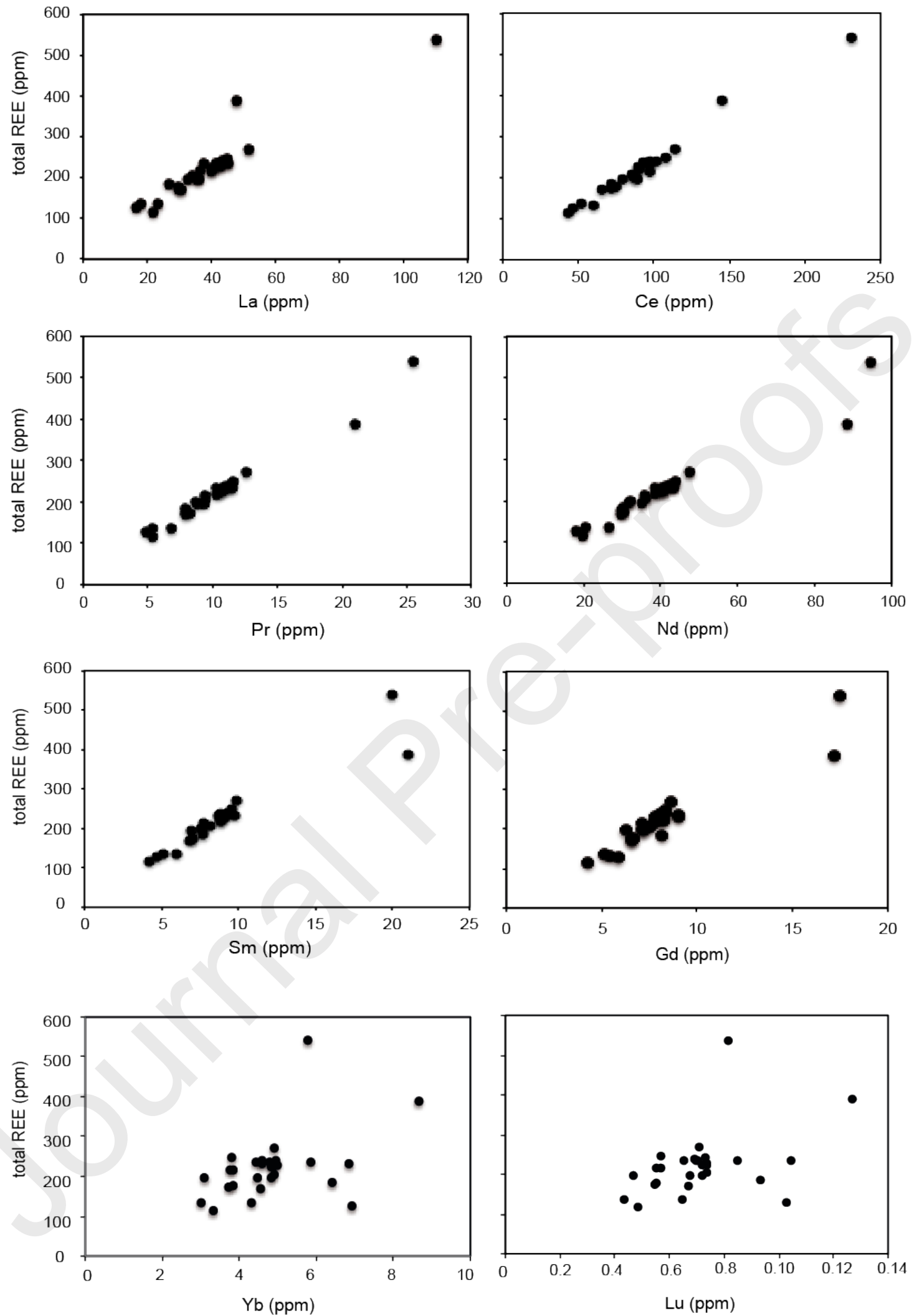

Fig. 15 

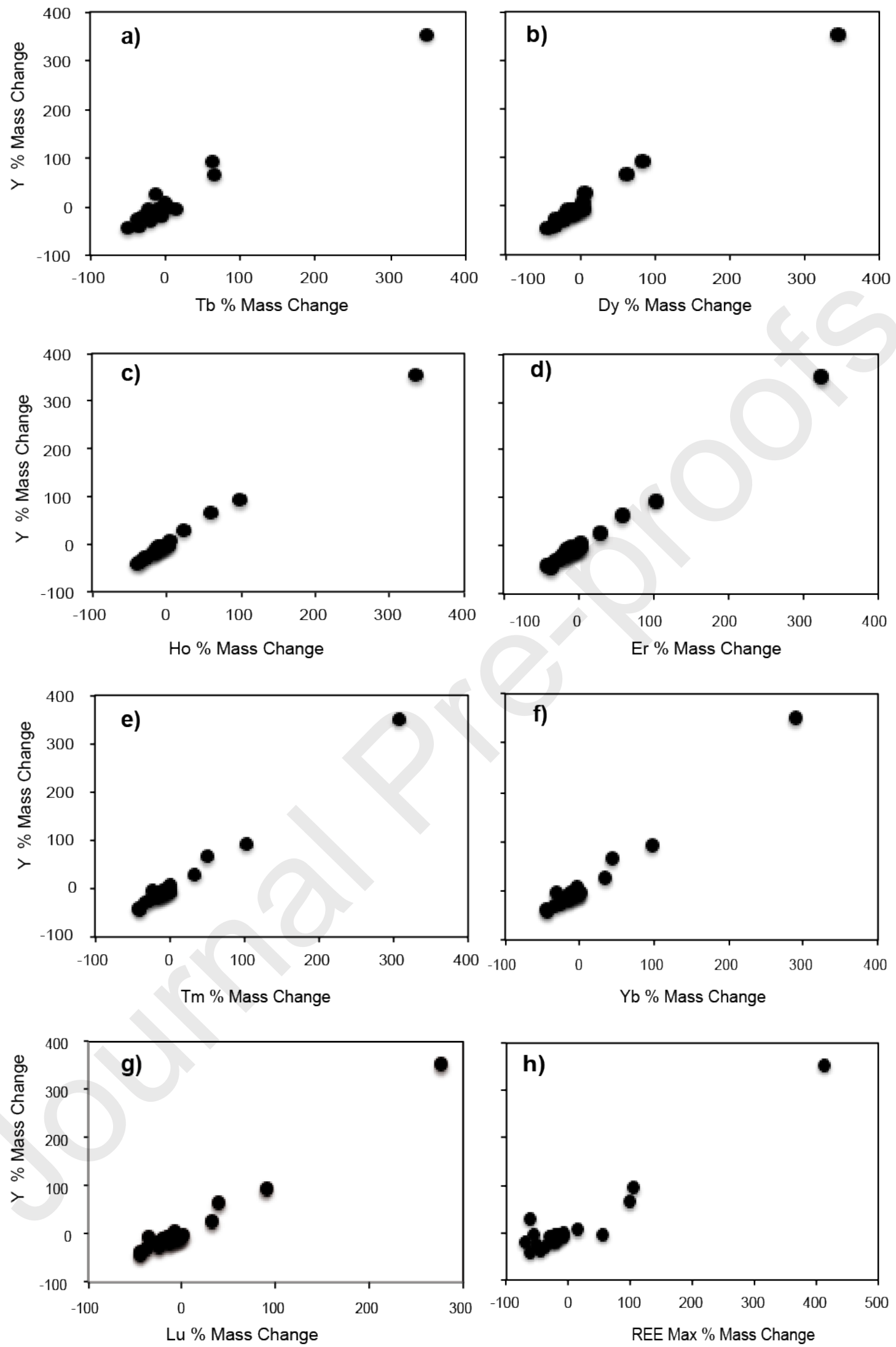

Fig. 16 

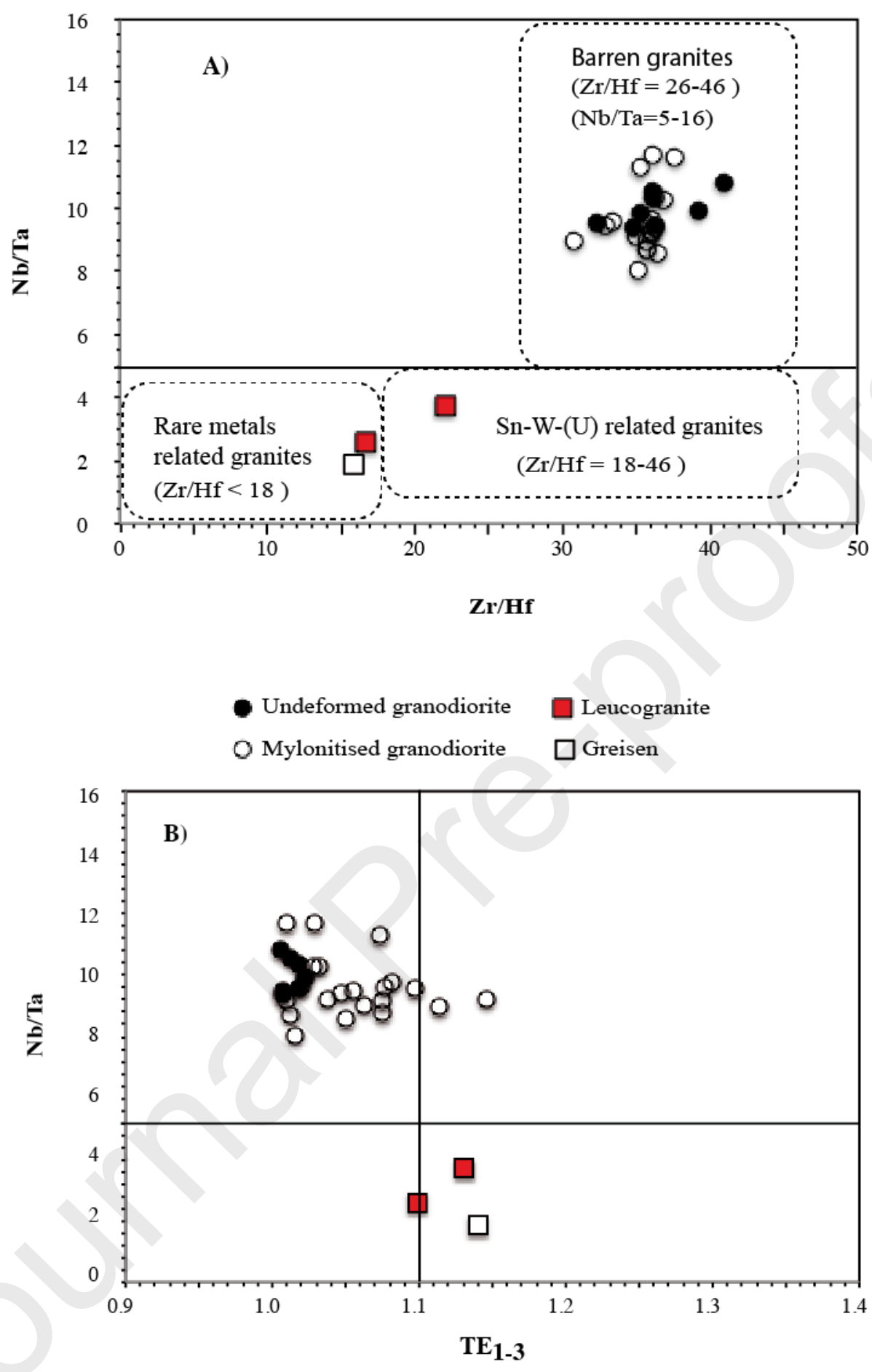

Fig. 17 

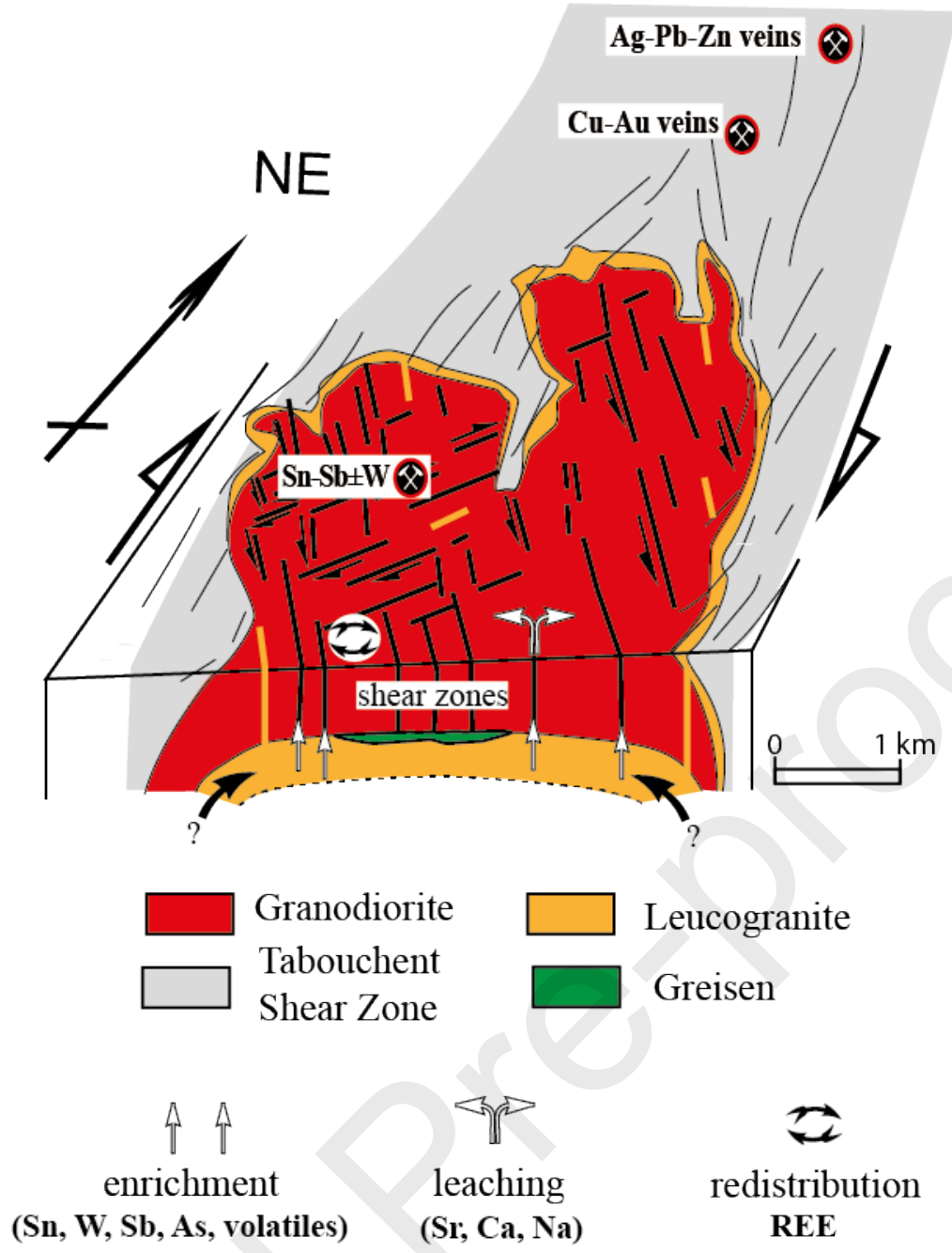

Fig. 18 
Table 1. Electron microprobe analyses of silicate minerals (* from El Amrani, 1994), L.D.

(Detection limit)

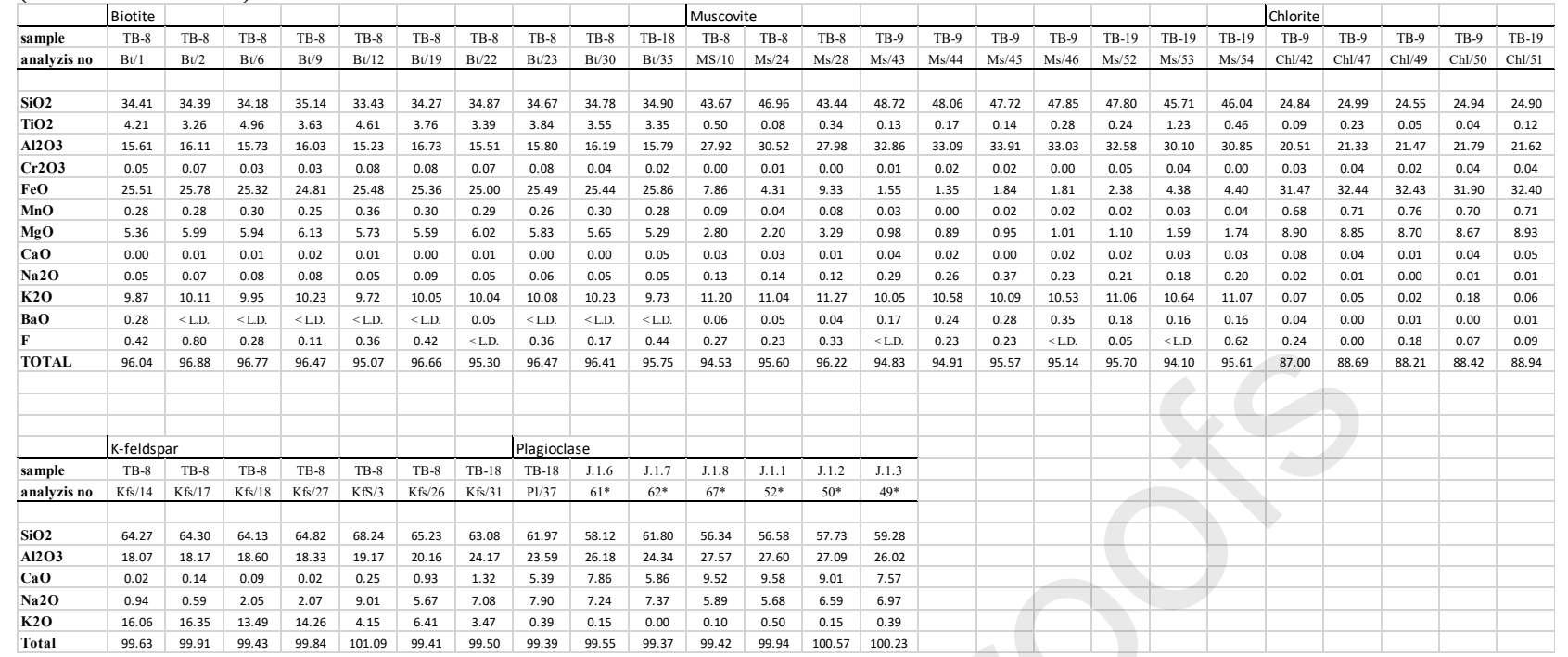


Table 2. Geochemical data of Tabouchent shear zones and their undeformed counterparts.

Samples extend from the weakly deformed to undeformed granodiorite (isotropic GD) in the isotropic domains outside the shear zones to ultramylonites and mylonites in the inner parts of the shear zones. Depending on the outcrop of the share zone sampled, each profile comprises three, two or exceptionally one sample. Geochemical data of a leucogranite dyke crosscutting Tabouchent granodiorite, and leucogranite ang greisen from Bramram are also presented (for sample locations, see Fig. 3).

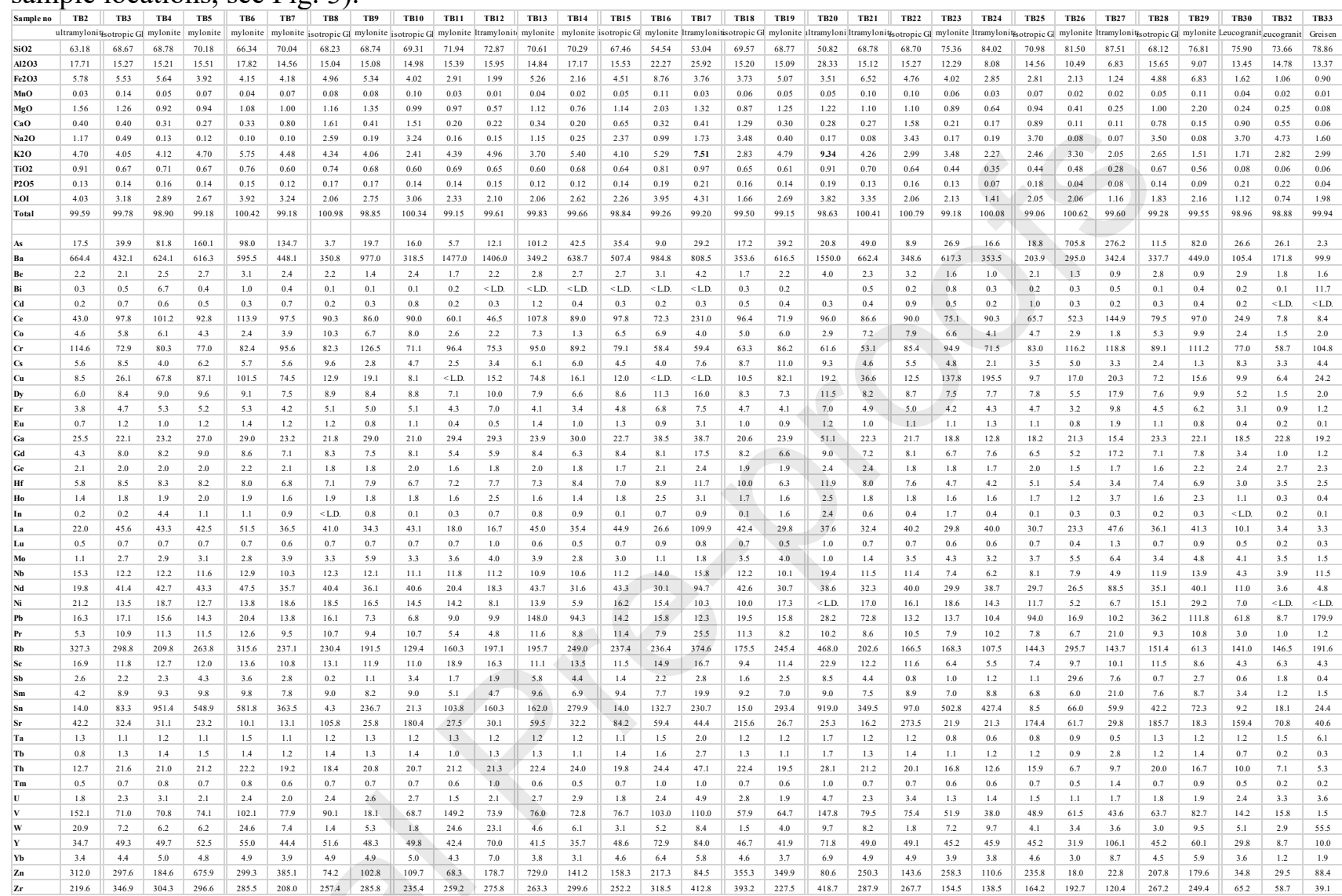

\section{Highlights}

The Tabouchent granodiorite is intruded by leucogranite and crosscut by shear zones

The shearing event transformed the granodiorite into phyllonites at $305.9+/-$ $0.9 \mathrm{Ma}$

The breakdown of feldspar into muscovite resulted in leaching of $\mathrm{Ca}$ and $\mathrm{Na}$ The dissolution/re-precipitation of syntectonic monazite resulted in REE mobilization

Acidic magmatic fluids exsolved from the leucogranite induced enrichments in Sn and W 

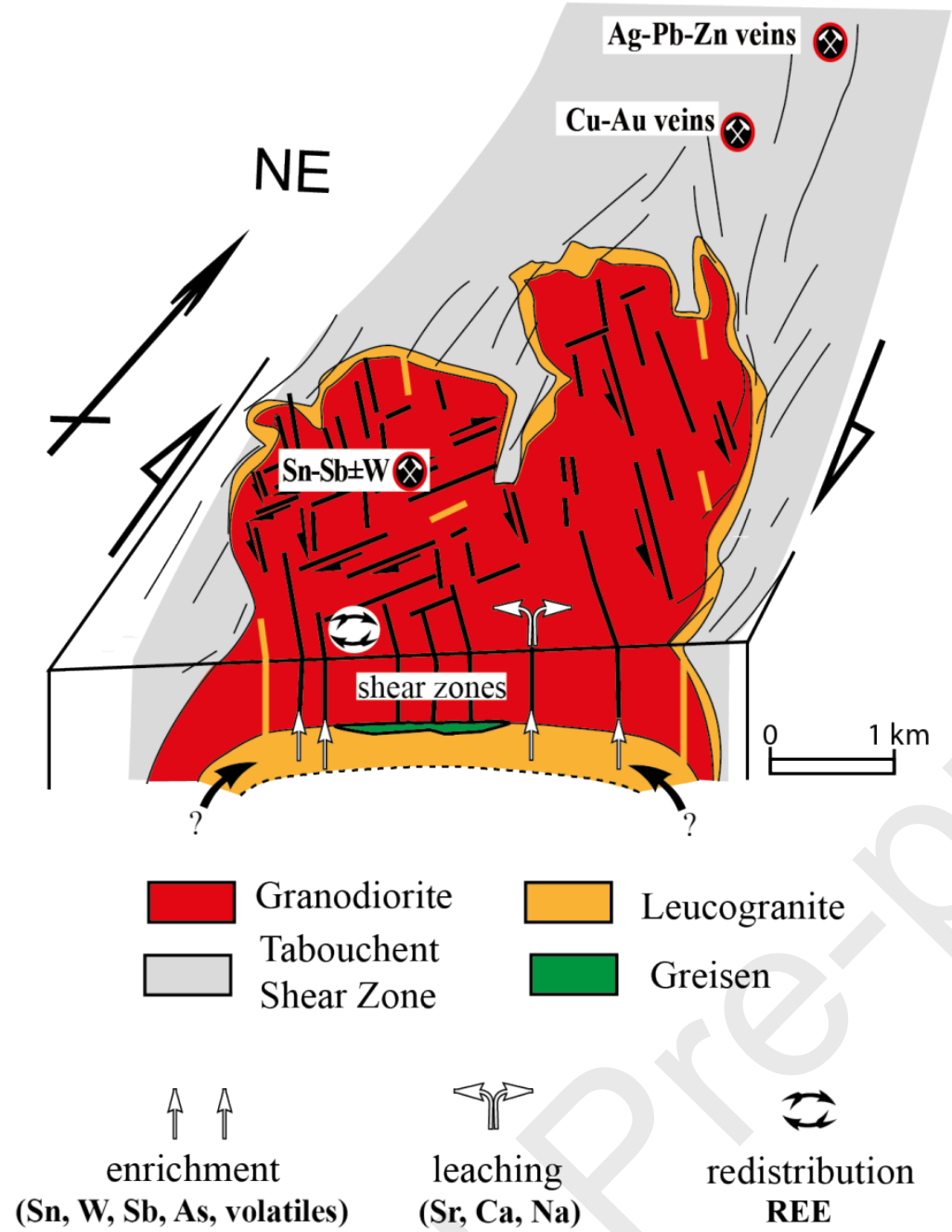